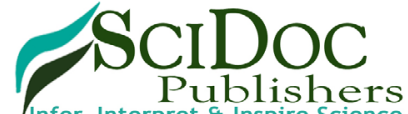

Publishers

\title{
Mechanistic Toxicity Assessment of Hexahydroisohumulone in Canine Hepatocytes, Renal Proximal Tubules, Bone Marrow-Derived Mesenchymal Stem Cells, and Enterocyte-like Cells
}

\author{
Research Article
}

Choi $\mathrm{K}^{1}$, Koci $\mathrm{J}^{1}$, Ortega $\mathrm{MT}^{1}$, Jeffery $\mathrm{B}^{2}$, Riviere $\mathrm{JE}^{1}$, Monteiro-Riviere $\mathrm{NA}^{1 *}$

${ }^{1}$ Department of Anatomy and Physiology, College of Veterinary Medicine, Kansas State University, Manhattan, KS, USA.

${ }^{2}$ Mars Global Food Safety Center, Yanqi Economic Development Zone, Huairou, Beijing, China.

\section{Abstract}

In vitro test methods are used primarily for rapid screening of chemicals based on mechanistic understanding of toxicity to predict hazards and potential risks. We investigated organ-specific oxidative stress and the molecular mechanism of toxicity using the pathway-focused DNA array of the hop ingredient hexahydroisohumulone (HEX) with canine hepatocytes, canine proximal tubule cells (CPTC), bone marrow-derived mesenchymal stem cells (BMSC) and enterocyte-like cells (ELC). Free radical species were produced in HEX-treated hepatocytes and to a lesser extent in CPTC, BMSC and ELC. Transcriptional profiles showed 30.5\% (113 genes) out of 370 genes were differentially expressed in hepatocytes followed by CPTC (21.6\%, 80 genes), ELC (4.8\%, 18 genes) and BMSC (1.0\%, 4 genes). HEX predominantly affected DNA damage/ repair pathways in hepatocytes and CPTC, while for ELC endoplasmic reticulum (ER) stress/unfolded protein response (UPR) dominated. Cyclooxygenase-2 (COX-2) and C/EBP homologous protein (CHOP) were most abundant genes in HEX-treated hepatocytes and CPTC; networked complementary between various pathways resulting in its adverse effect on oxidative stress, ER stress/UPR, mitochondrial metabolism and apoptosis. This work contributes to the understanding of the molecular effects of HEX, cellular response to oxidative stress and provides insight into genes altered with HEX exposure and the cell-type specific responses in dogs.

Keywords: In vitro Canine Systems; Hexahydroisohumulone; Oxidative Stress; Mechanisms of Action; Cyclooxygenase-2

\section{Introduction}

Humulus lupulus L., a member of the Cannabaceae family is a perennial and flowering plant. The female flowers of Humulus lupulus L. are commonly known as hops and are used as a beer ingredient. In herbal medicine, hops have been used as a sedative, as a mild hypnotic agent for anxiety and insomnia, and as an analgesic aid [1]. Iso $\alpha$-acids (isohumulones) are the isomerized forms of $\alpha$-acids hops that are formed during wort-boiling in the production of beer, and upon further hydrogenation and borohydride treatment, will yield a reduced isohumulone $[2,3]$. Reduced isohumulones were introduced decades ago to improve isohumulone decomposition by oxidation and photochemical processes. There are three different reduced isohumulones; tetrahydroisohumulone (TRA), hexahydroisohumulone (HEX) and rho-isohumulone [3, 4]. In vivo and in vitro studies in rats and mice suggest that isohumulones and reduced isohumulones had anti-cancer activity in Fischer 344 rats, anti-inflammatory activity in $\mathrm{C} 57 \mathrm{BL} / 6$ mice, $\mathrm{KK}-\mathrm{A}^{\mathrm{y}}$ mice and murine macrophage cell line RAW 264.7, and enhancement of glucose and lipid metabolism in C57BL/6 mice and Wistar rats [5-10]. Humulone at a dose of $50 \mu \mathrm{mol} / \mathrm{mL}$ reduced phorbol ester-induced cyclooxygenase-2 (COX-2, prostaglandin-H-synthase EC 1.14.99.1), an inflammatory mediator in ICR mouse skin [11]. In vitro exposure to $R$ ho isohumolone $(20 \mu \mathrm{g} / \mathrm{mL})$ suppresses the level of COX2 protein in RAW 264.7 cells [12]. In humans rho isohumolone at $1000 \mathrm{mg} /$ day reduced the clinical symptoms of patients with knee osteoarthritis in a 6 -week trial [12]. Hop extract $(18.1 \%$

Citation: Choi K, Koci J, Ortega MT, Jeffery B, Riviere JE, Monteiro-Riviere NA, (2016) Mechanistic Toxicity Assessment of Hexahydroisohumulone in Canine Hepatocytes, Renal Proximal Tubules, Bone Marrow-Derived Mesenchymal Stem Cells, and Enterocyte-like Cells. Int J Vet Health Sci Res. 4(2), 88-103. doi: http://dx.doi.org/10.19070/2332-2748-1600022

Copyright: Monteiro-Riviere NA ${ }^{\circ}$ 2016. This is an open-access article distributed under the terms of the Creative Commons Attribution License, which permits unrestricted use, distribution and reproduction in any medium, provided the original author and source are credited.
} 
humulone) inhibited COX-2-mediated prostaglandin $\mathrm{E}_{2}\left(\mathrm{PGE}_{2}\right)$ production in antibiotic A23187-stimulated human whole blood [13]. In contrast, we recently reported that HEX in dogs caused a cytotoxic response in canine hepatocytes, canine proximal tubule cells (CPTC), bone marrow-derived mesenchymal stem cells (BMSC) and enterocyte-like cells (ELC) [14]. HEX at $100 \mathrm{mg} / \mathrm{kg}$ causes an increase in serum alkaline phosphatase levels in beagle dogs, not purportedly due to liver toxicity, and was considered to be the no observed adverse effect level (NOAEL) [2]. There are several reported cases that dogs ingesting hops showed symptoms of malignant hyperthermia, a life-threatening disorder of skeletal muscles, whereas the natural extractives of hops are generally recognized as safe (GRAS) for human consumption [15, 16]. However, to our knowledge comprehensive safety analysis of HEX and its possible mechanism of action in dogs have not been characterized. This would be required before its adoption into pet foods for better assessment of species-and organ-specific responses to HEX.

Alternative in vitro test methods are important tools to improve our understanding of the adverse health effects from chemicals and to accurately predict their toxicity in humans or other species. Alternative screening methods can also help to reduce, refine, and replace animal testing. It is also important to assess the safety of chemicals to the target species. In vitro cell systems are used principally for screening purposes and to generate additional comprehensive toxicological profiles that can predict in vivo effects. Mechanism-based in vitro test strategies for risk characterization have been applied in risk assessment, for example in assessing the safety of food additives for the calculation of data-derived uncertainty factors [17-20]. In vitro cell systems in humans and animals have been utilized to obtain mechanism-derived information such as changes in gene expression or signaling pathways for the safety assessment of drugs, environmental chemicals, natural ingredients, and pet food ingredients [21-27].

Oxidative stress occurs with an increase in reactive oxygen species (ROS) production with sensitivity to free-radical species with a compromised cellular antioxidant capacity. This results in direct or indirect ROS-mediated damage in nucleic acids, proteins and lipids that may suggest neurodegenerative and cardiovascular diseases [28, 29]. A cellular ROS response to a toxicant has been considered an early biomarker of toxicity [17, 30]. Natural products and phytochemicals with antioxidant activity are utilized to delay and inhibit oxidation; but may also serve as prooxidants like carotenoids and flavonoids [31]. Isohumulones showed antioxidant activity in Dahl salt-sensitive (DS) rats and mouse macrophage RAW 264.7 cells, but TRA served as a poor antioxidant against the highly reactive hydroxyl radical [32-34]. Thus, it is not clear whether HEX intake may be beneficial or harmful to general health.

The goal of this study is to investigate 1) HEX-dependent oxidative stress in canine hepatocytes, CPTC, BMSC and ELC eliciting free radical-mediated toxicity; 2) ROS-induced damage on the cellular transcriptional network regulated by COX-2 using pathway-focused DNA array and; 3) cell type-specific pathways in HEX toxicity, representing the organ-specific mechanism of action in the main metabolizing organ the liver, the elimination organ the kidney, and to a lesser degree the metabolizing but main absorptive organ, the intestine.

\section{Materials and Methods}

\section{Chemicals}

Hexalone $^{\circledR}$ (Lot 154542K) accounting for 20\% (wt/wt) of hexahydroisohumulone in a propylene glycol solution (HEX, CAS 685110-34-3) was donated from Kalsec ${ }^{\circledR}$ Inc. (Kalamazoo, MI). All other chemicals, if not specified, were purchased from Sigma Aldrich (St. Louis, MO).

\section{Animals}

Dogs from which the liver ( 2 male and 1 female, $n=3$ ), kidney ( 3 female, $n=3$ ) and femur and tibia bones ( 1 male and 2 female, $\mathrm{n}=3$ ) obtained for these studies were of indeterminate breeds ranging from 1.5 - 9 years of age and 4.9-35.3 kg of body weight. These dogs were housed in individual rooms with a $12 \mathrm{hr}$ lightdark cycle. Dogs were fed a commercial dog food daily with free access to water. Before euthanasia, dogs were anesthetized with a 1:1 mixture of ketamine and xylazine (i.v., 55 to $74 \mu \mathrm{l} / \mathrm{kg}$ ) followed by euthanization with sodium pentobarbital (i.v., $222 \mu \mathrm{l} / \mathrm{kg}$ ) after owner consent. The dogs used in this study were not bred for this project. The liver, kidney, femur and tibia bones, were removed to obtain hepatocytes, proximal tubule cells, and bone marrow-derived mesenchymal stem cells (BMSC), respectively. This research was conducted with approval by the University's Institutional Animal Care and Use Committee Protocol 3214.

\section{Cell Culture Methods}

Canine hepatocytes: Canine hepatocytes were isolated with twostep collagenase perfusion followed by cryopreservation, and the cryopreserved canine hepatocytes were thawed by the previously described methods [35]. Cell viability and yield were estimated by trypan blue staining. The resulting hepatocytes (an average viability of $\sim 85 \%$ ) were resuspended in $10 \%(\mathrm{v} / \mathrm{v})$ fetal bovine serum (FBS) in complete Clonetics ${ }^{\mathrm{TM}}$ Hepatocyte Basal Medium $\left(\mathrm{HBM}^{\mathrm{TM}}\right)$ supplemented with Clonetics ${ }^{\mathrm{TM}}$ Hepatocyte Culture Medium (HCM ${ }^{\mathrm{TM}}$ ) single Quot kit (Lonza, Walkersville, MD). $\mathrm{HCM}^{\mathrm{TM}}$ single Quot kit also included ascorbic acid, fatty acid freebovine serum albumin, hydrocortisone, human epidermal growth factor, transferrin, insulin, gentamicin and amphotericin-B. Hepatocytes in complete HBM with 10\% FBS were plated in 6-well collagen/gelatin-coated plates and/or 96-well plates at a seeding density of $2 \times 10^{6}$ viable cells/well in a volume of 0.12 $\mathrm{mL} /$ well and a $0.6 \times 10^{5}$ viable cells/well in a volume of $2 \mathrm{~mL} /$ well, respectively. After $5 \mathrm{hr}$ of incubation at $37^{\circ} \mathrm{C}$, hepatocytes were overlaid with ice-cold Matrigel $(0.25 \mathrm{mg} / \mathrm{ml}$, Corning Life Sciences, Tewksbury, MA) and placed in the incubator for 48 hr. Cultures were maintained with complete HBM with $2 \%$ FBS $(\mathrm{v} / \mathrm{v})$ and the medium replaced every $24 \mathrm{hr}$.

Canine proximal tubule cells: The isolation of canine proximal tubule cells (CPTC), cryopreservation and the thawing procedure were performed by the previously described methods [26, 35]. The resulting pellets of CPTC were resuspended in complete Epithelial Cell Medium (EpiCM) (ScienCell ${ }^{\mathrm{TM}}$, Carlsbad, CA) supplemented with EpiGS, 2\% (v/v) FBS, $96 \mathrm{U} / \mathrm{mL}$ penicillin and $96 \mu \mathrm{g} / \mathrm{mL}$ streptomycin (ScienCell ${ }^{\mathrm{TM}}$, Carlsbad, CA); CPTC were plated in 96-well plates at $4 \times 10^{3} /$ well and T25 culture flasks at $3.12 \times 10^{5}$. All of the cell cultures were incubated, at $37^{\circ} \mathrm{C}$, 
in a humidified atmosphere of 95\% air and 5\% $\mathrm{CO}_{2}$. After 24 hr of incubation, CPTC medium was changed and maintained in complete EpiCM every 48 hr.

\section{Canine bone marrow-derived mesenchymal cells and} enterocyte-like cells: The isolation of canine bone marrowderived mesenchymal stem cells (BMSC), cryopreservation and the thawing procedure were accomplished as previously described $[27,35]$. Further, canine BMSC between passage 9 and 12 were selected and further differentiated into enterocyte-like cells (ELC) using the methods previously described [27]. In order to assess the ELC differentiation and metabolic capacity, intestinal alkaline phosphatase (IAP, AF250845.1), and glutathione-S-transferase alpha 3 (GSTA3, XM_532173) were chosen as previously described [36, 37] and their mRNA expression levels were quantified. The expression of the genes was normalized to that of the housekeeping gene (HKG), glyceraldehyde-3-phosphate dehydrogenase (GAPDH, NM_001003142). The average cycle threshold $(\mathrm{Ct})$ value of GSTA3 in differentiated ELC, derived from 3 dogs, was $21.2 \pm 4.5$ and for IAP $27.1 \pm 2.8$. The primer sequences used are summarized in Table 1 . The cDNA synthesis and PCR condition are described below. The BMSC and ELC were suspended in complete mesenchymal stem cell expansion media (MSCEM, Cellular Engineering Tech., Inc., Coralville, IA) with $10 \%(\mathrm{v} / \mathrm{v})$ FBS and ELC in complete DMEM/F12 (Life Tech., Carlsbad, CA) supplemented with 2\% (v/v) FBS, 2\% (v/v) B-27 supplement (Life tech., Carlsbad, CA), 1\% (v/v) N2 supplement (Life tech., Carlsbad, CA), 2mM glutamine (Life tech., Carlsbad, CA) and 1\% (v/v) NEAA (EMD Millipore, Billerica, MA) as well as $20 \mathrm{ng} / \mathrm{mL}$ epidermal growth factor (Preprotech Inc., Rocky Hill, NJ), respectively. Cells were plated in 96-well plates at 7 x $10^{3} /$ well and T25 culture flasks at $2.16 \times 10^{4}$. After $24 \mathrm{hr}$ of incubation, the media were changed and maintained in complete MSCEM and in complete DMEM/F12 and changed at $48 \mathrm{hr}$.

Oxidative and nitrative stress assessments for hepatocytes, CPTC, BMSC, and ELC

Time-and concentration-dependent production of HEX-induced oxidative stress was measured in four different canine cell culture systems using the total reactive oxygen species (ROS)/superoxide (SO) detection kit (Enzo Life Sciences, Farmingdale, NY)

Table 1. Primer sequences for quantitative Real-Time PCR.

\begin{tabular}{|c|c|c|}
\hline Gene symbol & Primer Sequence (5’ $\left(3^{\prime}\right)$ & Amplicon size \\
\hline \multirow[t]{2}{*}{ ACAA1 } & SENSE 5'-TGCCT'TTGTCCACTGTCAATA-3' & $95 \mathrm{bp}$ \\
\hline & ANTISENSE 5'-GCCAATGTCATAAGACCCATTTC-3' & \\
\hline \multirow[t]{2}{*}{ BAD } & SENSE 5'-CCAGCCGCAAACACCAT-3' & $102 \mathrm{bp}$ \\
\hline & ANTISENSE 5'-GCTATTCT'TCCTCCATTCCTTC-3’ & \\
\hline \multirow[t]{2}{*}{ CASP3 } & SENSE 5'-TGCCGAGGTACAGAACTAGA-3' & $90 \mathrm{bp}$ \\
\hline & ANTISENSE 5'-GTCCGCTTCGACTGGTATT'T-3' & \\
\hline \multirow[t]{2}{*}{ CYP19A1 } & SENSE 5’-CCATGTCTGTCTCTGTGTTCTT'-3' & $87 \mathrm{bp}$ \\
\hline & ANTISENSE 5'-CAGCCTGGATCTCCT'TCATTAT'T-3' & \\
\hline \multirow[t]{2}{*}{ PTGS2 (COX-2) } & SENSE 5'-GTGCCTGGTCTGATGATGTATG-3' & $85 \mathrm{bp}$ \\
\hline & ANTISENSE 5'-ATTCTGGGTGCTCCTGTTTAAG-3' & \\
\hline \multirow[t]{2}{*}{ RAD51 } & SENSE 5'-CATGT'TTGCTGCAGATCCTAAA-3' & $91 \mathrm{bp}$ \\
\hline & ANTISENSE 5'-CCCTCTTCCT'TTCCTCAGATAC-3' & \\
\hline \multirow[t]{2}{*}{ SLC51A } & SENSE 5'-CTCTTCCTCAGACCTGGATTTG-3' & $94 \mathrm{bp}$ \\
\hline & ANTISENSE 5'-AGGAAATCCTGTGCCCATT'TA-3' & \\
\hline \multirow[t]{2}{*}{ SOD1 } & SENSE 5'-GTCCACGAGAAACGAGATGAC-3' & $94 \mathrm{bp}$ \\
\hline & ANTISENSE 5'-CAATGACACCACAAGCCAAAC-3' & \\
\hline \multirow[t]{2}{*}{ ТР53 } & SENSE 5'-CGCGCTATGGCCATCTATAA -3' & $95 \mathrm{bp}$ \\
\hline & ANTISENSE 5'-AGACCGTCACTACTGTCAGA-3' & \\
\hline \multirow[t]{2}{*}{ ECHS1 } & SENSE 5'-GGTCAAGCCGGTCATAG -3' & $101 \mathrm{bp}$ \\
\hline & ANTISENSE 5'-GGGCT'TTCTCTCCAGCATAA-3' & \\
\hline \multirow[t]{2}{*}{ UBQLN2 } & SENSE 5'-CGATCCACACAGCCTAGTAATG-3' & $101 \mathrm{bp}$ \\
\hline & ANTISENSE 5’-CCAAACGGGTTGCTATTTGTG-3' & \\
\hline \multirow[t]{2}{*}{ SDHD } & SENSE 5'-TGGACAAGTGGTTACTGACTATG -3' & 99 bp \\
\hline & ANTISENSE 5'-CAAAGCCCAGCAAAGGTTAAA-3' & \\
\hline \multirow[t]{2}{*}{ GSTA3 } & SENSE 5'-GATCAGAGAGAGAACAACAGATCG-3' & 148 bp \\
\hline & ANTISENSE 5'-GGAGTCAAGCTCTTCCACATAG-3' & \\
\hline \multirow[t]{2}{*}{ IAP } & SENSE 5'-CCGTGCGATTCCACACAT A & $106 \mathrm{bp}$ \\
\hline & ANTISENSE 5'-CAACTGACGCCAAACAGAAC & \\
\hline \multirow[t]{2}{*}{ GAPDH } & SENSE 5'-GAACGGGAAACTTGTCATCAAC -3' & $94 \mathrm{bp}$ \\
\hline & ANTISENSE 5'-AGACCGTCACTACTGTCAGA-3' & \\
\hline
\end{tabular}


according to the previously described method [35]. Briefly, canine hepatocytes, CPTC, BMSC and ELC in 96-well plates were treated with $0-2.12 \mathrm{mg} / \mathrm{mL}$ of HEX for the canine hepatocytes and CPTC, and 0-0.05 mg/mL of HEX for BMSC and ELC. In this study, the various concentration ranges were selected based on the cytotoxic responses of HEX and tetrahydroisohumulone (TRA) in canine hepatocytes $\left(\mathrm{LC}_{50}, 0.12\right.$ and $0.29 \mathrm{mg} / \mathrm{mL}$ ); for CPTC 0.03 and $0.01 \mathrm{mg} / \mathrm{mL}$; for BMSC 0.04 and 0.03 and $\mathrm{mg} / \mathrm{mL}$; for ELC 0.02 and $0.01 \mathrm{mg} / \mathrm{mL}$, and a metabolic inhibitory potency of Isoxanthohumol on human CYP450 enzymes ( $\mathrm{IC}_{50}$ values, $10 \mu \mathrm{M})$ that have been previously reported $[14,38]$. The plasma concentrations of other hop ingredients, dihydroisohumulone $(0.21$ to $0.76 \mathrm{mg} / \mathrm{mL})$ in white rabbits with a single IV dose of 25 $\mathrm{mg} / \mathrm{kg}$ were also considered for a selection of HEX dose level; for TRA 0.2 to $0.65 \mathrm{mg} / \mathrm{mL}$; and for isohumulone 0.04 to 0.65 $\mathrm{mg} / \mathrm{mL}$ [39]. For the canine hepatocytes, HEX was diluted in complete HBM; CPTC in complete EpiCM; BMSC in phenol redfree MSCEM with 10\% FBS; and ELC in complete phenol redfree DMEM/F12. Subsequently, the detection probes in the wash buffer (1: 2500 dilution, v/v) were added and the fluorescence intensity measured at $0,0.5,2,6,18$ and $24 \mathrm{hr}$ after incubation. Pyocyanin (the final concentration of $250 \mu \mathrm{M}$ ) was used as a ROS/RNS inducer and therefore served as a positive control. The detection probe interacted with a wide range of ROS/ reactive nitrogen species (RNS) including hydrogen peroxide $\left(\mathrm{H}_{2} \mathrm{O}_{2}\right)$, hydroxyl radicals ( $\left.\mathrm{HO} \cdot\right)$, peroxynitrite $\left(\mathrm{NO}_{3}{ }^{-}\right)$and peroxy radical (ROO) and to a lesser degree, hypochlorous acid (HCIO) and nitric oxide (NO); for superoxide (SO) detection probe SO anion radical $\left(\mathrm{O}_{2}^{-}\right)$. The values of fluorescence intensity were normalized to background levels in the cell-free medium in the absence and/or presence of HEX. The media with complete HBM for hepatocytes, complete EpiCM for CPTC and complete phenol red-free MSCEM for BMSC and complete phenol redfree DMEM/F12 for ELC served as the control. The change in the normalized fluorescence intensity was plotted as a fold change relative to the control.

\section{RNA extraction and molecular toxicology pathway $\mathbf{R T}^{2}$ PCR array analysis}

All four cell types, derived from 3 different dogs for each cell type, were treated with $\mathrm{HEX}$ at the final concentration of $0.11 \mathrm{mg} / \mathrm{mL}$ for hepatocytes, $0.05 \mathrm{mg} / \mathrm{mL}$ for CPTC, $0.043 \mathrm{mg} /$ $\mathrm{mL}$ for BMSC and $0.023 \mathrm{mg} / \mathrm{mL}$ for ELC. The same dosage regime was selected for all 4 different canine cell types as fully defined in the measurement of oxidative/nitrative stress above. Total RNA was harvested from canine hepatocytes, CPTC and BMSC and ELC according to the previously described methods [25-27]. RNA concentration and RNA quality were assessed with the Nanodrop ${ }^{\circledR}$ ND-1000 spectrophotometer (Thermo Fisher Sci. Inc., Waltham, MA) and Agilent's 2100 Bioanalyzer and RNA 6000 nano kit (Agilent Technologies, Santa Clara, CA), respectively. The (RIN) was calculated by the electrophoretic RNA measurement using an embedded algorithm in Agilent's 2100 expert software. Total RNA samples with an average RIN values of 8.8 of all four cell types (hepatocytes, CPTC, BMSC and ELC), with and without HEX, were chosen for further study as previously described [40]. One $\mu \mathrm{g}$ of total RNA was reversetranscribed into cDNA using $\mathrm{RT}^{2}$ First Strand kit (Qiagen Inc., Valencia, CA). The obtained cDNA was mixed with $\mathrm{RT}^{2} \mathrm{SYBR}$ green mastermix (Qiagen Inc., Valencia, CA) and then added to each well of the dog molecular Toxicology Pathway Finder RT ${ }^{2}$
Profiler ${ }^{\text {TM }}$ PCR arrays (Qiagen Inc., Valencia, CA). Real-time PCR cycling conditions of Quantstudio ${ }^{\text {TM }} 7$ Flex (Applied Biosystem, Foster City, CA) were 1) pre-incubated at $95^{\circ} \mathrm{C}$ for $\left.10 \mathrm{~min}, 2\right)$ with 40 amplification cycles of denaturation at $95^{\circ} \mathrm{C}$ for $15 \mathrm{~s}$ and annelation at $60^{\circ} \mathrm{C}$ for $1 \mathrm{~min}$, and 3) melting curve analysis performed at 70 cycles at $60^{\circ} \mathrm{C}$ for $10 \mathrm{~s}$. The RT $\mathrm{T}^{2}$ profiler PCR array, profiling the expression of 370 genes related to 15 different functional pathways, was used to describe the mechanism of action of HEX-induced hepatic and extra-hepatic toxicity in dogs. The pathways consisted of apoptosis, carrier-mediate transport, chemokines and cytokines expression, cholestasis, DNA damage/repair, endoplasmic reticulum (ER) stress/ unfolded protein response, fatty acid metabolism, heat shock response, immunotoxicity, mitochondrial energy metabolism, necrosis, oxidative stress/antioxidant response, phase I and II drug metabolism, phospholipidosis and steatosis. Additionally, 5 endogenous control genes of beta-actin (ACTB), beta-2microglobulin (B2M), glyceraldehyde-3-phosphate dehydrogenase (GAPDH), hypoxanthine phosphoribosyltransferase 1 (HPRT1), and ribosomal protein large P1 (RPLP1) were used for normalization.

\section{cDNA synthesis and Real-time PCR}

As evidenced from the RT ${ }^{2}$ PCR arrays, 12 genes with more than a 2-fold change in response to HEX exposure were further analyzed for the differential expressions by quantitative realtime PCR analysis. RNA (20 ng) was reverse-transcribed using SuperScript ${ }^{\circledR}$ VILO $^{\text {TM }}$ MasterMix (Invitrogen ${ }^{\text {TM }}$, Carlsbad, CA), immediately followed by PCR amplification using Power SYBR ${ }^{\circledR}$ Green PCR MasterMix (Applied Biosystems, Carlsbad, CA). Quantitative PCR was performed with the Quantstudio ${ }^{\text {TM }} 7$ Flex (Applied Biosystem, Foster City, CA). The primer sequences used are summarized in Table 1. The PCR cycling conditions was carried out at $95^{\circ} \mathrm{C}$ for $10 \mathrm{~min}$ followed by 40 cycles of $95^{\circ} \mathrm{C}$ for $15 \mathrm{~s}$ and $60^{\circ} \mathrm{C}$ for $1 \mathrm{~min}$ and a melting curve $\left(70\right.$ cycles at $60^{\circ} \mathrm{C}$ for $10 \mathrm{~s})$. The expression of the genes was normalized to GAPDH (NM_001003142) as a HKG and their relative quantifications were performed as described above. All PCR reactions were carried out in triplicate.

\section{Statistical analysis}

Oxidative/nitrative stress measurements: An analysis of variance (ANOVA) for the oxidative/nitrative stress measurements was conducted to evaluate the main effect of concentrations, time points, and interactions (concentrations $\mathrm{x}$ time points) in each experiment. Fisher's protected least significant difference (LSD) was used to separate the means at the $5 \%$ level. All statistical analyses were performed in SAS 9.3 (SAS Institute, Cary, NC).

$\boldsymbol{R T}^{2} \boldsymbol{P C R}$ array analysis: Cycle threshold (Ct) exported from QuantStudio Real time PCR software v1.1 was utilized to calculate the changes in gene expression of interest using the RT ${ }^{2}$ profile PCR array data analysis webportal (http://www.qiagen. com/us/products/genes $\% 20$ and $\% 20$ pathways/data-analysiscenter-overview-page/). Briefly, $\Delta \mathrm{Ct}$ for each gene of interest (GOI) was calculated using Ct values for GOI and HKG for normalization, followed by averaging $\Delta \mathrm{Ct}$ for each gene across those replicate arrays for each group. A target gene expression level for each group was calculated as $2^{\text {-average } \Delta \mathrm{Ct}}$. Gene differential expression was expressed as fold change of expression in HEX- 
treated group compared with the control group. The fold change $<-2$ and $>2$, with a p-value less than 0.05 , represent down- and up-regulation of gene of interest, respectively.

\section{Results}

Oxidative and nitrative stress measurements

To validate the oxidative/nitrative stress induction in response to HEX exposure, ROS/RNS levels were determined using noninvasive fluorescent probes for monitoring ROS/RNS and SO. Canine hepatocytes were exposed to $0-2.12 \mathrm{mg} / \mathrm{mL}$, CPTC 0 $-2.12 \mathrm{mg} / \mathrm{mL}$, BMSC $0-0.05 \mathrm{mg} / \mathrm{mL}$, and ELC $0-0.05 \mathrm{mg} / \mathrm{mL}$ of HEX for $24 \mathrm{hr}$.

Canine hepatocytes: The production of ROS/RNS is illustrated in Figure 1A. ANOVA displayed the significant changes by concentrations $(p<0.0001)$ and time points effects $(p<0.0001)$ observed for ROS/RNS in canine hepatocytes. The significant effect of interaction (concentrations $\mathrm{x}$ time points) was observed for SO production $(\mathrm{p}=0.01)$ but not for ROS $/ \mathrm{RNS}$ production $(\mathrm{p}=0.12)$. The production of ROS/RNS is accumulated since the culture medium was not replaced during the $24 \mathrm{hr}$ period. As shown in Figure 1A, ROS/RNS production increased significantly with an increase in HEX concentrations over time. The final concentration of $0.04 \mathrm{mg} / \mathrm{mL}$ of HEX caused a 3-fold increase in ROS/RNS production in canine hepatocytes at $6 \mathrm{hr}$, reaching a plateau at $18 \mathrm{hr}$. The production of ROS/RNS at $2 \mathrm{hr}$ was 4.4 -fold increased at $1.06 \mathrm{mg} / \mathrm{mL}$ and 6.2 -fold at $2.12 \mathrm{mg} /$ $\mathrm{mL}$, confirming a clear dose-response relationship.

The result of SO production of HEX in canine hepatocytes is illustrated in Figure 3. The significant increase in SO production was found at $2.12 \mathrm{mg} / \mathrm{mL}$ (an 8.2-fold increase) at $0.5 \mathrm{hr}$, which remained for up to $24 \mathrm{hr}$.

Canine proximal tubule cells: ROS/RNS productions are shown in Figure 1B. ANOVA displayed that the significant changes by concentrations $(p<0.0001)$, time points $(p<0.0001)$ and interaction (concentrations $x$ time points) effects $(\mathrm{p}<0.0001)$ were observed for ROS/RNS and SO production in CPTC. The production of ROS/RNS in CPTC showed a 1.2- and 1.5-fold increase at 1.06 and $2.12 \mathrm{mg} / \mathrm{mL}$ of $\mathrm{HEX}$ at $18 \mathrm{hr}$.

The production of SO in CPTC by HEX was not determined from $1.36 \times 10^{-5} \mathrm{mg} / \mathrm{mL}$ to $2.12 \mathrm{mg} / \mathrm{mL}$ (data not shown).

Bone marrow-derived mesenchymal cells: The production of ROS/RNS in BMSC is shown in Figure 2A. In canine BMSC the significant changes by concentrations $(p<0.0001)$ were observed for ROS/RNS production, whereas no significant effect of time was noted $(p=0.06)$. The production of ROS/RNS had a 2 -fold increase at $0.05 \mathrm{mg} / \mathrm{mL}$ of HEX and at $6 \mathrm{hr}$ onward. However, HEX caused no production of SO in ELC from $4 \times 10^{-4} \mathrm{mg} / \mathrm{mL}$ to $0.05 \mathrm{mg} / \mathrm{mL}$.

Enterocyte-like cells: The result for ROS/RNS production is shown in Figure 2B. In canine ELC, significant changes by concentrations $(\mathrm{p}<0.0001)$, time points $(\mathrm{p}<0.0001)$ and interactions (concentrations $x$ time points) effects $(p<0.0001)$ were observed for ROS/RNS production. The ROS/RNS production at $0.01 \mathrm{mg} / \mathrm{mL}$ of HEX at $6 \mathrm{hr}$ had a 2.1 -fold increase which continued a gradual increase up to $24 \mathrm{hr}$. The highest concentration of HEX $(0.05 \mathrm{mg} / \mathrm{mL})$ caused a 3.5 -fold increase in ROS/RNS production at $6 \mathrm{hr}$, reaching the plateau up to $24 \mathrm{hr}$. The production of SO was not determined from $4 \times 10^{-4} \mathrm{mg} / \mathrm{mL}$ to $0.05 \mathrm{mg} / \mathrm{mL}$ of $\mathrm{HEX}$.

Figure 1. Hexahydroisohumulone (HEX)-induced ROS/RNS productions in canine hepatocytes (A) and CPTC (B) from 0 - 24 hr. Values are mean \pm standard deviation (3 biological replicates per cell type). Pyocyanin (PC) served as a positive control. Different letters denote significant differences between each concentration and time. $* \mathrm{p}<0.05, * * \mathrm{p}<0.005, * * * \mathrm{p}$ $<0.0001$.

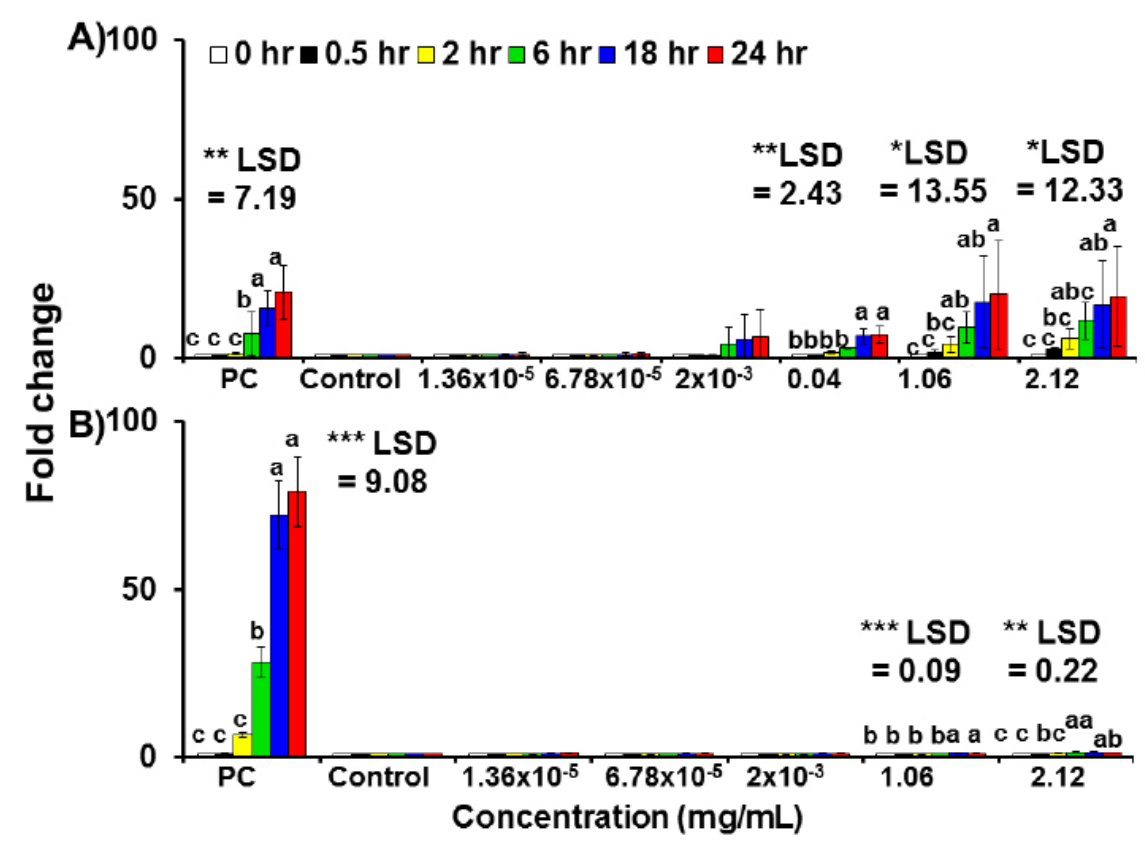


Figure 2. Hexahydroisohumulone (HEX)-induced ROS/RNS productions in BMSC (A) and ELC (B) from 0 - 24 hr. Values are mean \pm standard deviation (3 biological replicates per cell type). Pyocyanin (PC) served as a positive control. Different letters denote significant differences between each concentration and time. ${ }^{*} \mathrm{p}<0.05, * * \mathrm{p}<0.005, * * * \mathrm{p}<0.0001$.

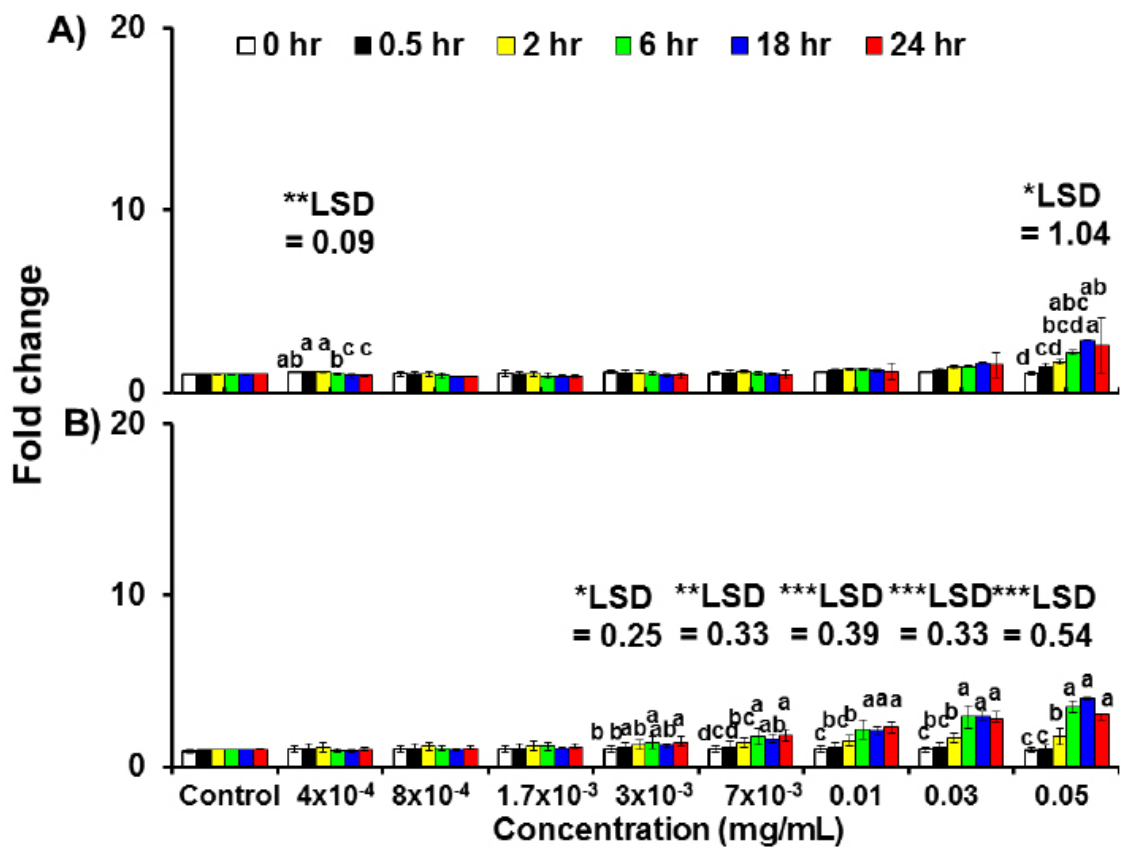

Figure 3. Hexahydroisohumulone (HEX)-induced SO productions in canine hepatocytes from 0 - 24 hr. Values are mean \pm standard deviation (3 biological replicates per cell type). Different letters denote significant differences between each concentration and time. $* \mathrm{p}<0.05$.

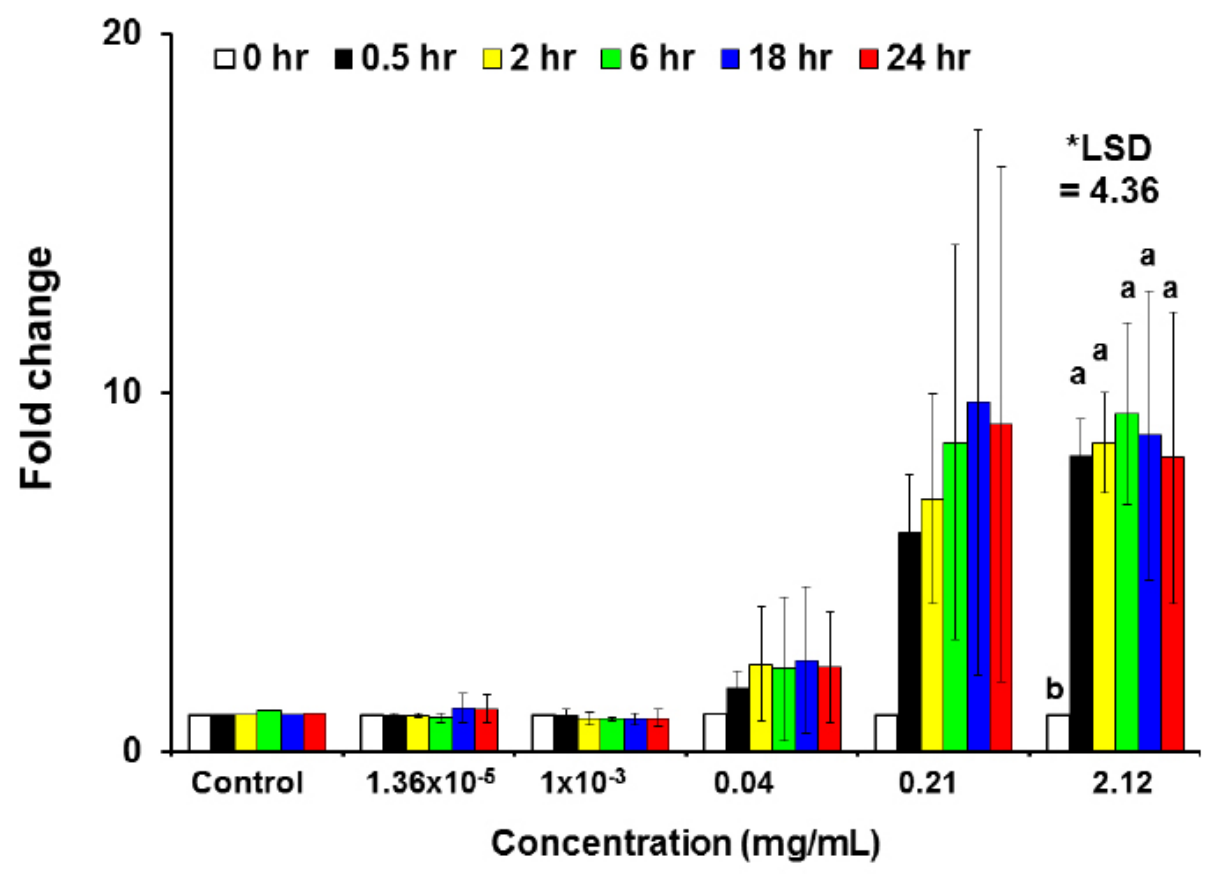

Hexahydroisohumulone - modulated gene expression

Exposure of canine hepatocytes, CPTC, BMSC and ELC to HEX at the cytotoxic concentrations of $0.11 \mathrm{mg} / \mathrm{mL}, 0.05 \mathrm{mg} /$ $\mathrm{mL}, 0.043 \mathrm{mg} / \mathrm{mL}$ and $0.023 \mathrm{mg} / \mathrm{mL}$, for $24 \mathrm{hr}$ resulted in the differential expression of genes represented by RT ${ }^{2}$ PCR array. Transcriptional profile indicated that $30.5 \%$ (113 genes) of the total genes (370 genes) in hepatocytes was significantly changed followed by CPTC (21.6\%, 80 genes), ELC (4.8\%, 18 genes) and BMSC (1.0\%, 4 genes). The commonly expressed genes by HEX treatment were $11.8 \%$ (44 genes) between hepatocytes and CPTC; $1.6 \%$ (6 genes) between hepatocytes and ELC; and 1\% (4 genes) between hepatocytes, CPTC and ELC. Using various gene ontology algorithms, these genes were divided into 15 distinct functional pathways and were summarized in Tables 2-6. ABCB11, CES2, CYP19A1, GSTA3, GSTM1, IL-8, PON1, SOD1 and SLC51A were involved in more than one functional pathway. 
Table 2. Upregulated and downregulated genes for apoptosis, necrosis and phospholipidosis pathway in canine hepatocytes, CPTC, BMSC and ELC in response to HEX for $24 \mathrm{hr}$. Three biological replicates per cell type were used.

\begin{tabular}{|c|c|c|c|c|c|c|}
\hline \multicolumn{4}{|c|}{ Fold changes vs. vehicle control } & \multirow[t]{2}{*}{ Ref Seq } & \multirow{2}{*}{$\begin{array}{l}\text { Gene } \\
\text { Symbol }\end{array}$} & \multirow[t]{2}{*}{ Description } \\
\hline Hepatocytes & CPTC & BMSC & ELC & & & \\
\hline \multicolumn{7}{|l|}{ Apoptosis } \\
\hline-11.19 & -2.38 & NS & 2.87 & XM_548413 & ABL1 & C-abl oncogene 1 , non-receptor tyrosine kinase \\
\hline-4.06 & -2.39 & NS & NS & XM_539737 & APAF1 & Apoptotic peptidase activating factor 1 \\
\hline-12.26 & -2.4 & NS & NS & NM_001031820 & BAD & BCL2-associated agonist of cell death \\
\hline-5.3 & -3.09 & NS & NS & NM_001020808 & BAK1 & BCL2-antagonist/killer-like \\
\hline NS & -2.09 & NS & NS & NM_001003011 & BAX & BCL2-associated X protein \\
\hline-4.29 & LR & NS & NS & NM_001003072 & BCL2L1 & BCL2-like 1 \\
\hline-3.07 & NS & NS & NS & XM_543733 & BID & $\mathrm{BH} 3$ interacting domain death agonist \\
\hline NS & -2.8 & NS & NS & NM_001080725 & BIRC3 & Baculoviral IAP repeat containing 3 \\
\hline-2.53 & -2.44 & NS & NS & NM_001003042 & CASP3 & Caspase 3, apoptosis-related cysteine peptidase \\
\hline-5.24 & LR & NS & NS & XM_544026 & CASP7 & Caspase 7 , apoptosis-related cysteine peptidase \\
\hline-4.1 & -5.24 & NS & NS & NM_001048029 & CASP8 & Caspase 8 , apoptosis-related cysteine peptidase \\
\hline-3.3 & LS & NS & NS & NM_001031633 & CASP9 & Caspase 9 , apoptosis-related cysteine peptidase \\
\hline NS & -4.03 & NS & NS & NM_001002982 & CD40 & TNF receptor superfamily member 5 , CD40 \\
\hline NS & -10.46 & NS & NS & NM_001002981 & CD40LG & CD40 ligand \\
\hline-2.91 & LR & NS & NS & XM_003639677 & FADD & Fas (TNFRSF6)-associated via death domain \\
\hline-8.25 & NS & NS & NS & XM_543595 & FAS & Fas (TNF receptor superfamily, member 6) \\
\hline-3.16 & -2.65 & NS & NS & NM_001003016 & MCL1 & Myeloid cell leukemia sequence 1 (BCL2-related) \\
\hline-10.78 & NS & NS & NS & XM_539146 & TNFRSF11B & $\begin{array}{l}\text { Tumor necrosis factor receptor superfamily, } \\
\text { member } 11 \mathrm{~b}\end{array}$ \\
\hline-7.33 & -10.36 & NS & 3.24 & NM_001003210 & TP53 & Tumor protein $\mathrm{p} 53$ \\
\hline \multicolumn{7}{|l|}{ Necrosis } \\
\hline NS & -2.79 & NS & NS & XM_843970 & $\mathrm{BMF}$ & $\mathrm{Bcl} 2$ modifying factor \\
\hline-2.06 & LR & NS & NS & XM_005626021 & EIF5B & Eukaryotic translation initiation factor $5 \mathrm{~B}$ \\
\hline NS & -3.32 & NS & NS & XM_545481 & GALNT5 & $\begin{array}{l}\text { UDP-N-acetyl-alpha-D-galactosamine: polypep- } \\
\text { tide N-acetylgalactosaminyltransferase } 5\end{array}$ \\
\hline-3.58 & -2.06 & NS & NS & XM_540431 & GRB2 & Growth factor receptor-bound protein 2 \\
\hline-2.78 & NS & NS & NS & XM_546243 & KCNIP1 & $\mathrm{Kv}$ channel interacting protein 1 \\
\hline-4.33 & -2.12 & NS & NS & XM_005619008 & NUDT13 & $\begin{array}{l}\text { Nudix (nucleoside diphosphate linked moiety X)- } \\
\text { type motif } 13\end{array}$ \\
\hline-7.97 & NS & NS & NS & XM_543047 & SPATA2 & Spermatogenesis associated 2 \\
\hline-2.75 & NS & NS & NS & XM_005616466 & PVR & Poliovirus receptor \\
\hline-2.11 & LR & NS & NS & XM_005636771 & SP1 & Sp1 transcription factor \\
\hline-4.53 & NS & NS & NS & XM_005633029 & TNFAIP8L1 & Tumor necrosis factor, $\alpha$-induced protein 8 -like 1 \\
\hline NS & -15.71 & NS & NS & XM_848314 & TXNL4B & Thioredoxin-like 4B \\
\hline \multicolumn{7}{|c|}{ Phospholipidosis } \\
\hline NS & -2.62 & NS & NS & XM_003640093 & LSS & Lanosterol synthase \\
\hline-3.36 & NS & NS & NS & XM_005639236 & MANBA & Mannosidase, beta A, lysosomal \\
\hline-3.12 & NS & NS & NS & XM_859671 & $\mathrm{CES} 2 *$ & Carboxylesterase 2 \\
\hline
\end{tabular}

NS: no significance, LR: lower change $(-2<$ fold $<2),{ }^{*}$ also involved in Phase I drug metabolism. 
Table 3. Upregulated and downregulated genes for DNA damage \& repair, phase I and phase II drug metabolism in canine hepatocytes, CPTC, BMSC and ELC in response to HEX for $24 \mathrm{hr}$. Three biological replicates per cell type were used.

\begin{tabular}{|c|c|c|c|c|c|c|}
\hline \multicolumn{4}{|c|}{ Fold changes vs. vehicle control } & \multirow[t]{2}{*}{ Ref Seq } & \multirow[t]{2}{*}{ Gene Symbol } & \multirow[t]{2}{*}{ Description } \\
\hline Hepatocytes & CPTC & BMSC & ELC & & & \\
\hline \multicolumn{7}{|c|}{ DNA Damage \& Repair } \\
\hline-2.53 & -2.3 & 6.09 & NS & NM_001145119 & APEX1 & $\begin{array}{l}\text { APEX nuclease (multifunctional DNA re- } \\
\text { pair enzyme) } 1\end{array}$ \\
\hline-4.6 & -3.36 & NS & NS & NM_001130828 & ATM & Ataxia telangiectasia mutated \\
\hline-8.63 & -7.49 & NS & NS & NM_001013416 & BRCA1 & Breast cancer 1 , early onset \\
\hline-10.94 & -9.47 & NS & NS & NM_001006653 & BRCA2 & Breast cancer 2 , early onset \\
\hline-6.11 & NS & NS & NS & XM_532125 & CDKN1A & $\begin{array}{l}\text { Cyclin-dependent kinase inhibitor } 1 \mathrm{~A} \\
\text { (p21, Cip1) }\end{array}$ \\
\hline-9.75 & -3.83 & NS & NS & XM_847098 & CHEK1 & CHK1 checkpoint homolog (S. pombe) \\
\hline-2.31 & -2.77 & NS & NS & XM_543464 & CHEK2 & CHK2 checkpoint homolog (S. pombe) \\
\hline-2.72 & NS & NS & NS & XM_534944 & ERCC6 & $\begin{array}{l}\text { Excision repair cross-complementing ro- } \\
\text { dent repair deficiency, complementation } \\
\text { group } 6\end{array}$ \\
\hline-4.17 & -2.91 & NS & NS & XM_542663 & LIG4 & Ligase IV, DNA, ATP-dependent \\
\hline-4.98 & LR & NS & NS & NM_001003376 & MGMT & $\begin{array}{l}\text { O-6-methylguanine-DNA methyltrans- } \\
\text { ferase }\end{array}$ \\
\hline-2.36 & -2.65 & NS & NS & XM_854186 & MLH1 & MutL homolog 1 , nonpolyposis type 2 \\
\hline-7.93 & -3.95 & NS & NS & XM_537511 & MLH3 & MutL homolog 3 \\
\hline-6.37 & NS & NS & NS & XM_538482 & MSH2 & $\begin{array}{l}\text { MutS homolog } 2 \text {, colon cancer, nonpoly- } \\
\text { posis type } 1\end{array}$ \\
\hline NS & -4.89 & NS & NS & XM_541781 & OGG1 & 8-oxoguanine DNA glycosylase \\
\hline-3.1 & -3.48 & NS & NS & XM_534355 & PCNA & Proliferating cell nuclear antigen \\
\hline-3.42 & LR & NS & NS & NM_001006651 & PRKDC & $\begin{array}{l}\text { Protein kinase, DNA-activated, catalytic } \\
\text { polypeptide }\end{array}$ \\
\hline-3.82 & -6.12 & NS & NS & NM_001003043 & RAD51 & RAD51 homolog \\
\hline-2.82 & LR & NS & NS & XM_533727 & $\mathrm{XPC}$ & $\begin{array}{l}\text { Xerodermapigmentosum, complementa- } \\
\text { tion group C }\end{array}$ \\
\hline-2.31 & NS & NS & NS & XM_533653 & XRCC1 & $\begin{array}{l}\text { X-ray repair complementing defective re- } \\
\text { pair in Chinese hamster cells } 1\end{array}$ \\
\hline NS & -2.41 & NS & NS & XM_532771 & XRCC2 & $\begin{array}{l}\mathrm{X} \text {-ray repair complementing defective re- } \\
\text { pair in Chinese hamster cells } 2\end{array}$ \\
\hline NS & -4.77 & NS & NS & XM_536061 & XRCC5 & $\begin{array}{l}\text { X-ray repair complementing defective re- } \\
\text { pair in Chinese hamster cells } 5\end{array}$ \\
\hline \multicolumn{7}{|c|}{ Phase I Drug Metabolism } \\
\hline NS & -5.18 & NS & NS & NM_001159684 & CYP1B1 & $\begin{array}{l}\text { Cytochrome P450, family } 1 \text {, subfamily B, } \\
\text { polypeptide } 1\end{array}$ \\
\hline-4.51 & NS & NS & NS & XM_546969 & CYP3A12 & Cytochrome P450 3A12-like \\
\hline NS & -4.01 & NS & NS & XM_547466 & FMO4 & Flavin containing monooxygenase 4 \\
\hline NS & -7.89 & NS & NS & XM_853482 & FMO5 & Flavin containing monooxygenase 5 \\
\hline-4.14 & -2.62 & NS & NS & NM_001002969 & MAOA & Monoamine oxidase A \\
\hline-2.32 & LR & NS & NS & XM_843276 & ESD & Esterase D \\
\hline-2 & NS & NS & NS & XM_845126 & PON1* & Paraoxonase 1 \\
\hline \multicolumn{7}{|c|}{ Phase II Drug Metabolism } \\
\hline-2.55 & NS & NS & NS & XM_532173 & GSTA3* & Glutathione S-transferase alpha 3 \\
\hline NS & NS & NS & 2.06 & XM_537038 & GSTM1** & Glutathione S-transferase mu 1 \\
\hline
\end{tabular}

NS: no significance, LR: lower change $(-2<$ fold $<2)$, * also involved in oxidative stress \& antioxidant response, $* *$ also involved in phospholipidosis. 
Canine hepatocytes: A total of 113 differently expressed genes in canine hepatocytes included 3 upregulated and 110 downregulated genes. As shown in Table 2, a total of 15 (2 anti apoptotic and 13 proapoptotic) genes for the apoptosis pathway was downregulated in HEX-treated hepatocytes compared to controls. For antiapoptotic genes (cell survival) BCL2L1 and MCL1 were 4.2- and 3.1-fold decreased, respectively. For proapoptotic genes (cell death), the expression of BAD mRNA was 12.2- fold downregulated followed by ABL1 (11.1-fold), TNFRSF11B (10.7-fold), FAS (8.2-fold), TP53 (7.3-fold), BAK1 (5.3-fold), CASP7 (5.2-fold), CASP8 (4.1-fold), APAF1 (4.0-fold), CASP9 (3.3), BID (3.0-fold), FADD (2.9-fold) and CASP3 (2.5-fold). The expression levels of SPATA2, TNFAIP8L1, GRB2, KCNIP1 and PVR involved in tumor necrosis factor (TNF)-induced necrosis were 7.9-, 4.5-, 3.5-, 2.7- and 2.7-fold downregulated by HEX, respectively. SP-1, a MAP kinase involved in signaling of necrotic cell death is also decreased (2.1-fold). For phospholipidosis

Table 4. Upregulated and downregulated genes for immunotoxicity, oxidative stress/antioxidant response, cholestasis and steatosis in canine hepatocytes, CPTC, BMSC and ELC in response to HEX for $24 \mathrm{hr}$. Three biological replicates per cell type were used.

\begin{tabular}{|c|c|c|c|c|c|c|}
\hline \multicolumn{4}{|c|}{ Fold changes vs. vehicle control } & \multirow{2}{*}{ Ref Seq } & \multirow{2}{*}{$\begin{array}{l}\text { Gene Sym- } \\
\text { bol }\end{array}$} & \multirow{2}{*}{ Description } \\
\hline Hepatocytes & CPTC & BMSC & ELC & & & \\
\hline \multicolumn{7}{|c|}{ Immunotoxicity } \\
\hline NS & 4.23 & NS & NS & NM_001003200 & IL8 & Interleukin 8 \\
\hline 2.87 & NS & NS & NS & XM_542040 & KLF1 & Kruppel-like factor 1 \\
\hline NS & 8.97 & NS & NS & XM_531672 & LYZ & Lysozyme \\
\hline NS & -3.32 & NS & NS & XM_005637893 & MKI67 & Antigen identified by monoclonal antibody Ki-67 \\
\hline-4.26 & NS & NS & NS & XM_547371 & NR5A2 & Nuclear receptor subfamily 5 , group A, member 2 \\
\hline 10.38 & 60.74 & -4.04 & NS & NM_001003354 & PTGS2 & $\begin{array}{l}\text { Prostaglandin-endoperoxide synthase } 2 \text { (prostaglandin } \\
\text { G/H synthase/cyclooxygenase-2) }\end{array}$ \\
\hline-3.05 & -2.53 & NS & 3.88 & XM_549029 & UBQLN2 & ubiquitin-like protein (Ubiquilin) 2 \\
\hline \multicolumn{7}{|c|}{ Oxidative Stress \& Antioxidant Response } \\
\hline NS & -2.08 & NS & NS & XM_546693 & DHCR24 & 24-dehydrocholesterol reductase \\
\hline-5.44 & -3.09 & NS & NS & XM_548229 & EPX & Eosinophil peroxidase \\
\hline-3.66 & LR & NS & NS & XM_531773 & FHL2 & Four and a half LIM domains 2 \\
\hline-6.76 & NS & NS & NS & NM_001164454 & GPX3 & Glutathione peroxidase 3 \\
\hline NS & -2.27 & NS & NS & XM_005615617 & NCOA7 & Nuclear receptor coactivator 7 \\
\hline NS & NS & NS & 8.05 & XM_848524 & NQO1 & NAD $(\mathrm{P}) \mathrm{H}$ dehydrogenase, quinone 1 \\
\hline-3.15 & -4.24 & NS & NS & XM_547012 & NUDT1 & Nudix-type motif 1 \\
\hline-2.25 & NS & NS & NS & XM_003433082 & NUDT15 & Nudix-type motif 15 \\
\hline-3.17 & -2.38 & NS & NS & XM_545680 & PPP1R15B & $\begin{array}{l}\text { Protein phosphatase } 1 \text {, regulatory (inhibitor) subunit } \\
15 \mathrm{~B}\end{array}$ \\
\hline-3.45 & -3.86 & NS & NS & NM_001252165 & PRDX1 & Peroxiredoxin 1 \\
\hline-2.04 & LR & NS & NS & NM_001003035 & SOD1* & Superoxide dismutase 1, soluble \\
\hline \multicolumn{7}{|l|}{ Cholestasis } \\
\hline NS & LR & NS & 6.17 & XM_533394 & ATP8B1 & $\begin{array}{l}\text { ATPase, aminophospholipid transporter, class I, type } \\
\text { 8B, member } 1\end{array}$ \\
\hline-2.8 & -2.39 & NS & NS & XM_546524 & DLAT & Dihydrolipoamide S-acetyltransferase \\
\hline-17.34 & NS & NS & NS & XM_538073 & GJB1 & Gap junction protein, beta 1, (connexin 32) \\
\hline NS & LR & NS & 2.37 & XM_536581 & RDX & Radixin \\
\hline-16.05 & NS & NS & NS & NM_001143932 & $\mathrm{ABCB} 11^{\#}$ & $\begin{array}{l}\text { ATP-binding cassette, sub-family B (MDR/TAP), } \\
\text { member } 11\end{array}$ \\
\hline-3.47 & -5.48 & NS & NS & XM_846673 & SLC51A \# & Similar to organic solute transporter alpha \\
\hline \multicolumn{7}{|l|}{ Steatosis } \\
\hline-3.58 & -4.09 & NS & NS & XM_548250 & ACACA & Acetyl-CoA carboxylase alpha \\
\hline NS & 6.11 & NS & NS & XM_548370 & AGPAT2 & 1-acylglycerol-3-phosphate O-acyltransferase 2 \\
\hline NS & NS & NS & 2.03 & NM_001004074 & COMT & Catechol-O-methyltransferase \\
\hline NS & -4.95 & NS & NS & NM_001008715 & CYP19A1** & $\begin{array}{l}\text { Cytochrome P450, family 19, subfamily A, polypeptide } \\
1\end{array}$ \\
\hline NS & -2.16 & NS & NS & NM_001131049 & DNM1 & Dynamin 1 \\
\hline-2.3 & NS & NS & NS & XM_845287 & GPD1 & Glycerol-3-phosphate dehydrogenase 1 \\
\hline-4.51 & NS & NS & NS & NM_001287151 & LMNA & Lamin A/C \\
\hline NS & NS & NS & 2.54 & XM_534943 & MAPK8 & Mitogen-activated protein kinase 8 \\
\hline-6.25 & NS & NS & NS & XM_544995 & MTTP & Microsomal triglyceride transfer protein \\
\hline NS & -2.91 & NS & NS & XM_005634050 & PCCA & Propionyl CoA carboxylase, alpha polypeptide \\
\hline-2.72 & NS & NS & NS & XM_005625764 & PNPLA3 & Patatin-like phospholipase domain containing 3 \\
\hline
\end{tabular}

NS: no significance, LR: lower change $(-2<$ fold $<2),{ }^{*}$ also involved in immunotoxicity, \# also involved in carrier-mediated transport, ** also involved in Phase I metabolism 
MANBA and CES2 mRNA were moderately inhibited (3-fold) in the presence of HEX. In Table 3, for DNA damage/repair a total of 7 genes involved in double strand break repair showed a significant decrease in response to HEX. The rank order of downregulated genes was BRCA2 (10.9-fold) $\geq$ CHEK1 (9.7fold) $>$ BRCA1 (8.6-fold) > ATM (4.6-fold) $\cong$ LIG4 (4.1-fold) $\geq \operatorname{RAD} 51$ (3.8-fold) $\cong$ PRKDC (3.4-fold). The DNA mismatch repair genes MLH1 (2.3-fold), MSH2 (6.3-fold) and MLH3 (7.9-fold) decreased. Nucleotide and base excision repair genes PCNA, XPC, ERCC6 and APEX1 as well as XRCC1 mRNA were 3.1-, 2.8-, 2.7-, 2.5- and 2.3-fold decreased, respectively. The other genes related DNA repair such as MGMT, CDKN1A and CHEK2 were 4.9-, 6.1- and 2.3-fold downregulated. In phase I drug metabolism, CYP3A12 mRNA was 4.5-fold decreased; for MAOA 4.1-fold; and for ESD 2.3-fold. PON1 mRNA involved in both phase I metabolism, immunotoxicity and antioxidant against oxidized low-density lipoprotein had a 2 -fold decrease. GSTA3 mRNA involved in both phase II drug metabolism and immunotoxicity had a 2.5 -fold decrease. In Table 4, immunotoxicity-related genes PTGS2, also known as

Table 5. Upregulated and downregulated genes for fatty acid metabolism ( $\beta$-Oxidation) and ER Stress \& unfolded protein response in canine hepatocytes, CPTC, BMSC and ELC in response to HEX for 24 hr. Three biological replicates per cell type were used.

\begin{tabular}{|c|c|c|c|c|c|c|}
\hline \multicolumn{4}{|c|}{ Fold changes vs. vehicle control } & \multirow{2}{*}{ Ref Seq } & \multirow{2}{*}{ Gene Symbol } & \multirow{2}{*}{ Description } \\
\hline Hepatocytes & CPTC & BMSC & ELC & & & \\
\hline \multicolumn{7}{|c|}{ Fatty Acid Metabolism ( $\beta$-Oxidation) } \\
\hline-5.55 & -2.2 & NS & NS & XM_854439 & ACAA1 & Acetyl-CoA acyltransferase 1 \\
\hline-4.51 & -2.37 & NS & NS & XM_005636239 & ACAD10 & Acyl-CoA dehydrogenase family, member 10 \\
\hline-2 & NS & NS & NS & XM_005632086 & ACAD9 & Acyl-CoA dehydrogenase family, member 9 \\
\hline-3.06 & LR & NS & NS & XM_005622131 & ACADM & Acyl-CoA dehydrogenase, C-4 to C-12 straight chain \\
\hline-4.65 & NS & NS & NS & XM_005636308 & ACADS & Acyl-CoA dehydrogenase, C-2 to C-3 short chain \\
\hline-2.19 & LR & NS & NS & XM_535048 & ACADSB & Acyl-CoA dehydrogenase, short/branched chain \\
\hline-4.05 & LR & NS & NS & XM_546581 & ACADVL & Acyl-CoA dehydrogenase, very long chain \\
\hline-2.46 & NS & NS & NS & XM_546539 & ACAT1 & Acetyl-CoA acetyltransferase 1 \\
\hline NS & -2.09 & NS & NS & XM_541180 & ACAT2 & Acetyl-CoA acetyltransferase 2 \\
\hline NS & -7.05 & NS & NS & XM_547892 & ACOT2 & Acyl-CoA thioesterase 2 \\
\hline NS & NS & NS & 2.34 & XM_536727 & ACOT7 & Acyl-CoA thioesterase 7 \\
\hline-3.96 & -2.08 & NS & NS & XM_534440 & ACOT8 & Acyl-CoA thioesterase 8 \\
\hline-5.87 & NS & NS & NS & XM_545908 & ACOX3 & Acyl-CoA oxidase 3, pristanoyl \\
\hline-4.85 & -8.23 & NS & 3 & XM_546705 & CPT2 & Carnitine palmitoyltransferase 2 \\
\hline-5.33 & NS & NS & NS & XM_548425 & CRAT & Carnitine O-acetyltransferase \\
\hline-2.27 & NS & NS & NS & XM_535127 & DECR1 & 2,4-dienoyl CoA reductase 1, mitochondrial \\
\hline-3.95 & LR & NS & 2.53 & XM_537945 & ECHS1 & Enoyl CoA hydratase, short chain, 1 , mitochondrial \\
\hline-6.29 & NS & NS & NS & XM_533901 & GCDH & Glutaryl-CoA dehydrogenase \\
\hline \multicolumn{7}{|c|}{ ER Stress \& Unfolded Protein Response } \\
\hline NS & 2.09 & NS & NS & XM_854584 & ATF4 & $\begin{array}{l}\text { Activating transcription factor } 4 \text { (tax-responsive en- } \\
\text { hancer element B67) }\end{array}$ \\
\hline-2.82 & LR & NS & NS & XM_545777 & ATF6 & Activating transcription factor 6 \\
\hline 10.59 & 6.21 & NS & NS & XM_844109 & DDIT3 & $\begin{array}{l}\text { DNA-damage-inducible transcript } 3 \text { [C/EBP homolous } \\
\text { protein }(\mathrm{CHOP})]\end{array}$ \\
\hline-2.29 & LR & NS & NS & XM_532320 & DERL1 & Der1-like domain family, member 1 \\
\hline-4.92 & -2.5 & NS & NS & XM_537162 & EDEM3 & ER degradation enhancer, mannosidase alpha-like 3 \\
\hline NS & 8.53 & NS & NS & XM_547813 & ERO1L & $\begin{array}{l}\text { Endoplasmic reticulum oxidoreductase (ERO1)-like (S. } \\
\text { cerevisiae) }\end{array}$ \\
\hline-2.48 & NS & NS & NS & XM_546074 & ERO1LB & ERO1-like beta (S. cerevisiae) \\
\hline-2.06 & NS & NS & NS & XM_005626994 & ERP44 & Endoplasmic reticulum protein 44 \\
\hline NS & -2.29 & 4.57 & 2.72 & XM_005620647 & MBTPS1 & Membrane-bound transcription factor peptidase, site 1 \\
\hline-3.78 & NS & NS & 2.22 & XM_540482 & NPLOC4 & Nuclear protein localization 4 homolog (S. cerevisiae) \\
\hline NS & NS & NS & 2.4 & XM_541506 & NUCB1 & Nucleobindin 1 \\
\hline-2.57 & -2.32 & NS & NS & XM_846664 & SEC62 & SEC62 homolog (S. cerevisiae) \\
\hline NS & NS & NS & 2.79 & XM_537530 & SEL1L & Sel-1 suppressor of lin-12-like (C. elegans) \\
\hline-3.89 & -2.04 & NS & NS & XM_535603 & UBE2G2 & Ubiquitin-conjugating enzyme E2G 2 \\
\hline-2.93 & -2.42 & NS & NS & XM_847533 & VCP & Valosin containing protein \\
\hline
\end{tabular}

NS: no significance, LR: lower change $(-2<$ fold $<2)$ 
inducible cyclooxygenase-2 (COX-2) and KLF1, a transcription factor had a 10.3-fold and a 2.8-fold increase in response to HEX, while UBQLN2 [ubiquitin-like protein (ubiquilin)] and NR5A2, a transcription factor were moderately inhibited (3- to 4.2-fold). For oxidative stress/antioxidant response, a total 6 antioxidant genes were transcriptionally suppressed. The rank order of downregulated antioxidant genes was GPX3 (6.7-fold) $>\operatorname{EPX}(5.4$-fold) $>$ PRDX1 (3.4- fold) $\cong \operatorname{NUDT1~(3.1-~fold)~}$ $>$ NUDT15 (2.2- fold) $\cong$ SOD1 (2.0-fold). Cholestasis-mediated genes DLAT and GJB1 were 2.8- and 17.3-fold decreased, respectively. Expression of carrier-mediated transport genes ABCB11 and SLC51A involved in cholestasis had a 16.0-fold and a 3.4-fold decrease. The steatosis-related genes MTTP, LMNA, ACACA, PNPLA3 and GPD1 were significantly inhibited (2.3 to 6.2-fold). In Table 5, a total of 13 fatty acid metabolism-related genes ( 7 acyl-CoA dehydrogenases, 2 acetyl-CoA transferases, 2 carnitine transferases, 1 acyl-CoA thioesterases and 1 acyl-CoA oxidase) were significantly inhibited, ranging from moderate (2- to 3-fold) for ACAD9, ACADSB, ACAT1, ACADM to the most severe (3.9- to 6-fold) for ACOT8, ACADVL, ACAD10, ACADS, ACAA1, ACOX3, CPT2, CRAT and GCDH. In the endoplasmic reticulum (ER) stress/unfolded protein response (UPR), a total of 10 genes (1 upregulated and 9 downregulated) were significantly modified. The DDIT3, also known as C/EBP homologues protein (CHOP) was 10.5-fold induced with HEX. The rank order of 9 downregulated genes was EDEM3 (4.9-fold) $>\operatorname{UBE} 2 \mathrm{G} 2(3.8) \cong \operatorname{NPLOC} 4(3.7)>\operatorname{VCP}(2.9) \cong \operatorname{ATF} 6(2.8) \cong$ $\operatorname{SEC62~(2.5)\cong ERO1LB~(2.4)\cong DERL1~(2.2)\cong ~ERP44~(2.0).~In~}$ Table 6 , a total of 10 genes involved in mitochondria citric acid cycle were downregulated moderately (2- to 3-fold); 9 genes in heat shock response with a 2- to 4.6-fold inhibition.

Canine proximal tubule cells: As shown in Table 2, a total of 12 (2 antiapoptotic and 10 proapoptotic) genes in HEX-treated CPTC was downregulated ranging from moderate (2- to 3-fold) for BAX, ABL1, APAF1, BAD, CASP3, MCL1, BIRC3 and BAK1 to the most severe (4- to 10-fold) for CD40, CASP8, TP53 and CD40LG. TNF-induced necrosis-related genes TXNL4B, BMF, GALNT5, GRB2 and NUDT13 were 15.7-, 2.7-, 3.3-, 2.0- and 2.1-fold downregulated, respectively. The LSS mRNA, involved in phospholipidosis, showed a 2.6-fold downregulation. In Table 3, for DNA damage/repair, double strand break repairrelated gene BRCA2 (9.4-fold) was extensively inhibited followed by BRCA1 (7.4-fold), RAD51 (6.1-fold), XRCC5 (4.7-fold), CHEK1 (3.8-fold), ATM (3.3-fold), LIG4 (2.9-fold) and XRCC2 (2.4-fold). The DNA mismatch repair genes MLH1 (2.6-fold) and MLH3 (3.9-fold) decreased. Nucleotide and base excision repair genes OGG1, PCNA and APEX1 were 4.8-, 3.4- and 2.3-fold downregulated. The CHEK2 genes related to DNA repair had 2.7-fold downregulation. In phase I drug metabolism, FMO5 mRNA showed a 7.8-fold downregulation, compared to controls followed by CYP1B1 (5.1-fold), FMO4 (4.0-fold) and MAOA (2.6-fold). In Table 4, for the immunotoxicity pathway, COX2 mRNA was 60.7-fold induced with HEX followed by LYZ (8.9-fold) and IL-8 (4.2-fold). For oxidative stress/antioxidant response, antioxidant genes NUDT1 had a 4-fold downregulation followed by PRDX1 (3.8-fold), EPX (3.0-fold), NCOA7 (2.2fold) and DHCR24 (2.0-fold). The cholestasis-responsive genes DLAT and SLC51A showed a 2.3-fold and a 5.4-fold decrease. The steatosis-related genes CYP19A1, ACACA and PCCA as well as DNM1 were also downregulated (2.1- to 4.9-fold), while a 6-fold change in AGPAT2 mRNA was induced compared to the controls. In Table 5, fatty acid metabolism ( $\beta$-oxidation)-related genes ACAA1, ACAD10, ACAT2, ACOT2 and ACOT8 as well as CPT2 were significantly inhibited (2.0- to 8.2-fold). The ER stress/UPR genes ATF4, ERO1L and CHOP were induced (2.0to 8.5-fold), while EDEM3, MBTPS1, SEC62, UBE2G2 and VCP were slightly inhibited (2-fold). In Table 6, mitochondria citric acid cycle-mediated 4 genes (FH, IDH1, IDH3A and SDHD) were slightly suppressed; but IDH2 mRNA was 2-fold induced. For heat shock response HSPA1L mRNA was the most severely down-regulated (8-fold), while CRYAB and HSPA5 showed a 2.2fold and a 5.6-fold induction, respectively.

Bone marrow-derived mesenchymal cells: A total of 3 genes of BMSC showed a significant increase in response to HEX (Tables 3-6). The rank order of upregulated genes were APEX1 (6.0-fold) $>$ MBTPS1 (4.5-fold) > MDH1 (2.7-fold). The COX-2 mRNA showed a 4-fold decrease in response to HEX.

Enterocyte-like cells: In Table 2, for apoptosis ABL1 and TP53 mRNA of ELC was 2.8- and 3.2-fold induced, respectively, in the presence of HEX. The GSTM1 involved in phase II metabolism had a 2 -fold induction (Table 3). The UBQLN2 in immunotoxicity and NQO1 in oxidative stress/antioxidant response showed a 3.8-fold and an 8.0-fold increase, respectively (Table 4). The expression of cholestasis-related genes RDX and ATP8B1 was 2.3 - and 6.1-fold increased; for steatosis-related COMT and MAPK 8 mRNA a 2.0-fold and a 2.5 -fold increase, respectively. For fatty acid metabolism ACOT7, CPT2 and ECHS1 mRNA showed a 2.3-fold, a 3.0-fold and a 2.5-fold induction (Table 5). ER stress/UPR-related genes MBTPS1, NPLOC4, NUCB1 and SEL1L were moderately induced (2-fold). HSP90B1 and HSPB2 mRNA in heat shock response were significantly induced, ranging from a 2.0 -fold to a 6.1-fold change (Table 6).

To confirm the results of gene expression profiling from $\mathrm{RT}^{2}$ PCR array, quantitative real time PCR was used to examine the HEX effect on the transcriptional levels of 11 genes for hepatocytes, 10 genes for CPTC, 3 genes for ELC and 1 gene for BMSC. As shown in Table 7, HEX significantly modulated the transcript levels of ACAA1, BAD, RAD51, SDHD, SLC51A, and SOD1 in hepatocytes and CPTC with the varied degree of their expressions; for CASP3 in hepatocytes; for CYP19A1 in CPTC; for ECHS1 in canine hepatocytes and ELC; for TP53 and UBQLN2 in canine hepatocytes, CPTC and ELC; and for COX2 in canine hepatocytes, CPTC and BMSC. These transcriptional changes were consistent with those in gene expression profiling from RT ${ }^{2}$ PCR array.

\section{Discussion}

Alternative in vitro test methods are increasingly important for toxicity testing to assess the safety or hazards after exposure to various substances. The data from in vitro studies are used to strengthen the interpretation of in vivo toxicity results. In vitro to in vivo extrapolations (IVIVE) of toxic potencies are used to assess the quantitative hazard characterizations of food additives such as natural products [20]. This study presents organ-specific production of reactive oxygen and nitrogen species induced by hexahydroisohumulone (HEX) in canine hepatocytes, CPTC, BMSC and ELC. The regulatory mechanisms of cellular response to HEX-induced oxidative stress in canine liver were characterized 
at the molecular level. Furthermore, hepatic responses of gene expression were compared with those in the kidney and the intestine with respect to the molecular targets and mechanism of action of HEX.

\section{Oxidative stress measurement}

When canine hepatocytes were treated at higher concentrations or longer durations the current dose-response study on the radical production by HEX demonstrated a significant increase in ROS/ RNS level at its cytotoxic concentration promoting free radicalmediated toxicity of HEX (Figure 1A). However, extrahepatic production of ROS/RNS in CPTC, BMSC and ELC was limited compared to hepatocytes (Figures 1B, 2A, 2B). Additionally, the accumulation of SO by HEX in hepatocytes was also observed (Figure 3). These results are consistent with a recent in vitro study that a reduced isohumulone, tetrahydroisohumulone (TRA) caused concentration-and time-dependent oxidative stress in canine hepatocytes [35]. To a lesser degree, an extrahepatic production of ROS/RNS by HEX was observed in CPTC, BMSC and ELC (Figure 1B, 2A and 2B). In contrast to these results in primary canine cells, others reported that other hop components worked as antioxidants in vivo and in vitro [32-35]. Isohumulones had antioxidant activity in Dahl salt-sensitive

Table 6. Upregulated and downregulated genes for mitochondrial energy metabolism and heat shock response in canine hepatocytes, CPTC, BMSC and ELC in response to HEX for $24 \mathrm{hr}$. Three biological replicates per cell type were used.

\begin{tabular}{|c|c|c|c|c|c|c|}
\hline \multicolumn{4}{|c|}{ Fold changes vs. vehicle control } & \multirow{2}{*}{ Ref Seq } & \multirow{2}{*}{ Gene Symbol } & \multirow{2}{*}{ Description } \\
\hline Hepatocytes & CPTC & BMSC & ELC & & & \\
\hline \multicolumn{7}{|c|}{ Mitochondrial energy metabolism } \\
\hline-2.17 & NS & NS & NS & XM_845105 & ACLY & ATP citrate lyase \\
\hline-2.25 & NS & NS & NS & XM_844073 & $\mathrm{ACO} 2$ & Aconitase 2, mitochondrial \\
\hline-3.41 & -2 & NS & LR & XM_537215 & FH & Fumarate hydratase (fumarase) \\
\hline-3.14 & -2.5 & NS & NS & XM_536047 & IDH1 & Isocitrate dehydrogenase 1 (NADP+), soluble \\
\hline NS & 2.07 & NS & NS & XM_005618362 & IDH2 & $\begin{array}{l}\text { Isocitrate dehydrogenase } 2 \text { (NADP+), mitochon- } \\
\text { drial }\end{array}$ \\
\hline-3.51 & -2.08 & NS & LR & XM_536213 & IDH3A & Isocitrate dehydrogenase $3(\mathrm{NAD}+)$ alpha \\
\hline-3.09 & LR & NS & NS & XM_005634871 & IDH3B & Isocitrate dehydrogenase $3(\mathrm{NAD}+)$ beta \\
\hline-2.44 & NS & 2.76 & LR & XM_531844 & MDH1 & Malate dehydrogenase 1, NAD \\
\hline-3.95 & NS & NS & NS & XM_536042 & MDH1B & Malate dehydrogenase 1B, NAD \\
\hline-2.42 & -2.33 & NS & NS & XM_536573 & SDHD & $\begin{array}{l}\text { Succinate dehydrogenase complex, subunit } \mathrm{D} \text {, in- } \\
\text { tegral membrane protein }\end{array}$ \\
\hline-3.45 & NS & NS & NS & XM_542566 & SUCLA2 & Succinate-CoA ligase, ADP-forming, beta subunit \\
\hline \multicolumn{7}{|c|}{ Heat shock response } \\
\hline NS & 2.24 & NS & NS & XM_857165 & CRYAB & Crystallin, alpha B \\
\hline NS & -2.45 & NS & NS & NM_001252143 & DNAJA1 & DnaJ (Hsp40) homolog, subfamily A, member 1 \\
\hline-3.08 & LR & NS & NS & XM_536990 & DNAJA3 & DnaJ (Hsp40) homolog, subfamily A, member 3 \\
\hline-4.64 & NS & NS & NS & XM_005635314 & DNAJC5 & DnaJ (Hsp40) homolog, subfamily C, member 5 \\
\hline-2.17 & NS & NS & NS & XM_532154 & HSP90AB1 & $\begin{array}{l}\text { Heat shock protein } 90 \mathrm{kDa} \text { alpha (cytosolic), class } \\
\mathrm{B} \text { member } 1\end{array}$ \\
\hline NS & LR & NS & 6.17 & NM_001003327 & HSP90B1 & $\begin{array}{l}\text { Heat shock protein 90kDa beta (Grp94), member } \\
1\end{array}$ \\
\hline-3.33 & NS & NS & NS & XM_535180 & HSPA14 & Heat shock $70 \mathrm{kDa}$ protein 14 \\
\hline NS & -8 & NS & NS & XM_005627163 & HSPA1L & Heat shock 70kDa protein 1-like \\
\hline NS & -3.38 & NS & NS & XM_537479 & HSPA2 & Heat shock $70 \mathrm{kDa}$ protein 2 \\
\hline-2.3 & LR & NS & NS & NM_001048016 & HSPA4 & Heat shock $70 \mathrm{kDa}$ protein 4 \\
\hline NS & 5.67 & NS & NS & XM_858292 & HSPA5 & $\begin{array}{l}\text { Heat shock } 70 \mathrm{kDa} \text { protein } 5 \text { (glucose-regulated } \\
\text { protein, } 78 \mathrm{kDa} \text { ) }\end{array}$ \\
\hline NS & -3.79 & NS & NS & XM_005619650 & HSPA8 & Heat shock $70 \mathrm{kDa}$ protein 8 \\
\hline NS & LR & NS & 2.04 & XM_849018 & HSPB2 & Heat shock $27 \mathrm{kDa}$ protein 2 \\
\hline-3.9 & NS & NS & NS & NM_001003029 & HSPB8 & Heat shock $22 \mathrm{kDa}$ protein 8 \\
\hline-2.47 & NS & NS & NS & XM_005640496 & HSPD1 & Heat shock $60 \mathrm{kDa}$ protein 1 (chaperonin) \\
\hline-3.52 & NS & NS & NS & XM_003434292 & HSPE1 & Heat shock $10 \mathrm{kDa}$ protein 1 (chaperonin 10$)$ \\
\hline NS & -2.88 & NS & NS & XM_003639872 & HSPH1 & Heat shock $105 \mathrm{kDa} / 110 \mathrm{kDa}$ protein 1 \\
\hline-2.68 & NS & NS & NS & XM_541181 & TCP1 & T-complex 1 \\
\hline
\end{tabular}

NS: no significance, LR: lower change $(-2<$ fold $<2)$. 
Table 7. RT-PCR analysis of the transcript levels of genes altered by HEX in canine hepatocytes, CPTC, BMSC and ELC for $24 \mathrm{hr}$. Three biological replicates per cell type were used.

\begin{tabular}{|c|c|c|c|c|}
\hline & \multirow[t]{2}{*}{ Gene Symbol } & \multirow[t]{2}{*}{ Ref Seq } & \multicolumn{2}{|c|}{$\begin{array}{l}\text { Fold change } \\
\text { vs.vehicle control }\end{array}$} \\
\hline & & & Mean & S.D. \\
\hline \multirow{11}{*}{ Hepatocytes } & ACAA1 & XM_854439 & -6.2 & 2.7 \\
\hline & BAD & NM_001031820 & -19.12 & 12.3 \\
\hline & CASP3 & NM_001003042 & -6.39 & 0.6 \\
\hline & ECHS1 & XM_537945 & -6.72 & 1.5 \\
\hline & PTGS2 (COX-2) & NM_001003354 & 35.27 & 24.9 \\
\hline & RAD51 & NM_001003043 & -4.9 & 2.9 \\
\hline & SDHD & XM_536573 & -5.95 & 1 \\
\hline & SLC51A & XM_846673 & -2.52 & 1.4 \\
\hline & SOD1 & NM_001003035 & -9.99 & 9 \\
\hline & UBQLN2 & XM_549029 & -4.71 & 1.8 \\
\hline & TP53 & NM_001003210 & -5.23 & 1.4 \\
\hline \multirow{10}{*}{ СРTC } & ACAA1 & XM_854439 & -4.88 & 1.4 \\
\hline & BAD & NM_001031820 & -10.58 & 1.1 \\
\hline & CYP19A1 & NM_001008715 & -2.46 & 0.5 \\
\hline & PTGS2 (COX-2) & NM_001003354 & 57.54 & 13.8 \\
\hline & RAD51 & NM_001003043 & -9.26 & 3.1 \\
\hline & SDHD & XM_536573 & -5.6 & 2.2 \\
\hline & SLC51A & XM_846673 & -2.65 & 1.5 \\
\hline & SOD1 & NM_001003035 & -5.42 & 1.5 \\
\hline & TP53 & NM_001003210 & -2.96 & 0.6 \\
\hline & UBQLN2 & XM_549029 & -3.37 & 1.1 \\
\hline \multirow{3}{*}{ ELC } & ECHS1 & XM_537945 & 8.1 & 3.7 \\
\hline & TP53 & NM_001003210 & 5.55 & 0.9 \\
\hline & UBQLN2 & XM_549029 & 8.72 & 0.6 \\
\hline BMSC & PTGS2 (COX-2) & NM_001003354 & -4.1 & 2.5 \\
\hline
\end{tabular}

Figure 4. Proposed molecular mechanisms of HEX action according to the previous studies [51, 52, 58] and the results of gene expression profile in HEX-treated canine hepatocytes, CPTC and ELC. HEX increases COX-2 and CHOP expression, downregulates anti- and pro-apoptotic genes via PI3K/Akt and CHOP-dependent mechanisms and upregulates IL-8 expression. AP-1, activator protein 1; Akt, protein kinase B; cAMP, cyclic adenosine monophosphate; CFTP, cystic fibrosis transmembrane conductance regulator; EP2, prostaglandin E receptor 2; EP4, prostaglandin E receptor 4; MDM2, mouse double minute 2 homolog; NFkB, nuclear factor kappa B; PDK1, phosphoinositide-dependent kinase 2; PIP3, phosphatidylinositol $(3,4,5)$ trisphosphates; PI3K, phosphatidylinositol 3-kinase.

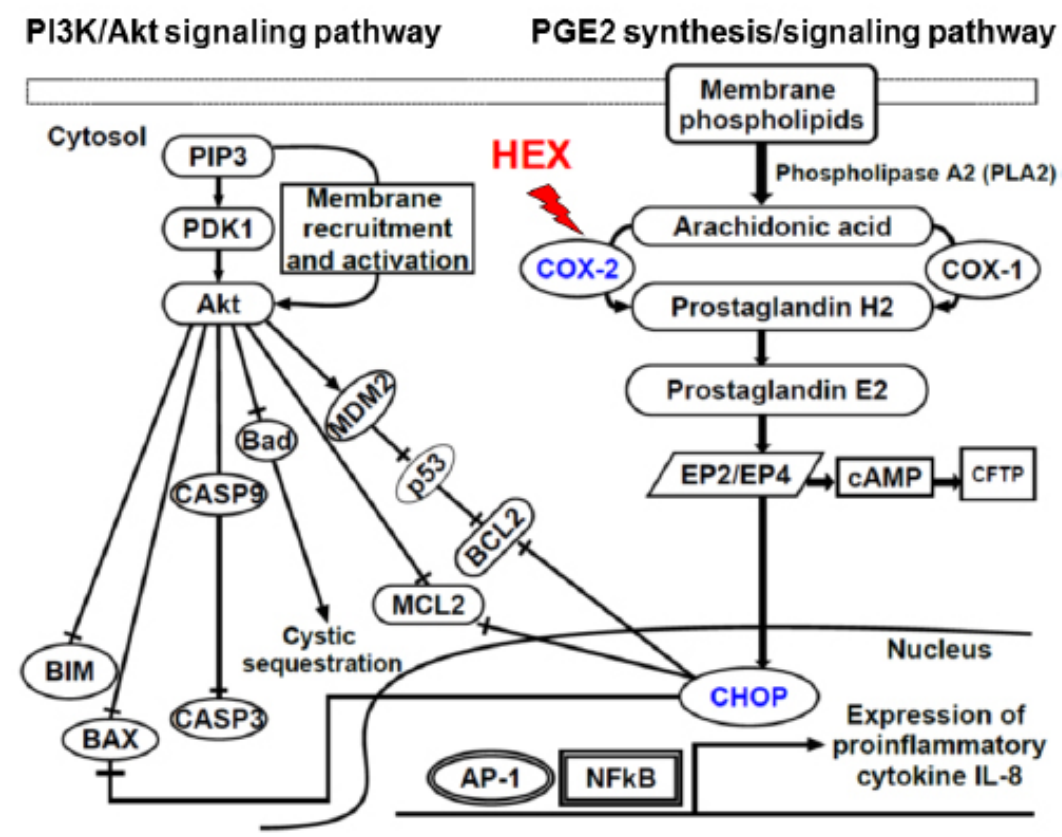

$\perp$ a direct inhibitory modification, $\downarrow$; a direct stimulatory modification 
(DS) rats fed a commercial diet containing $8 \% \mathrm{NaCl}$ and $0.3 \%$ isohumulone and in murine RAW 264.7 cells $\left(\mathrm{IC}_{50}\right.$ value of $5.9-18.4 \mu \mathrm{g} / \mathrm{mL})[32,33]$. TRA and xanthohumol moderately attenuated the production of peroxyl, singlet oxygen and hydroxyl radicals, and peroxy nitrite/ferric ion derived from a cell-free assay, respectively [34]. Our laboratory recently reported that TRA served as a strong antioxidant when CPTC were treated at higher concentrations and for longer periods of time, whereas it was a free radical producer in canine ELC [35]. The liver is an important target organ for cellular stress response, as an example of oxidative stress exposed to various pro-oxidant toxic substances and also plays an important role in the activation of antioxidant defense mechanisms. Our results suggest that HEX acts as a potent inducer of oxidative stress in canine liver and to a lesser degree in the kidney and the intestine. Consistent with the current study, an extensive hepatic production of free radical species, compared to extrahepatic production, occurred in rat when fed a beta-carotene supplement and in mice administrated with titanium dioxide $\left(\mathrm{TiO}_{2}\right)[41,42]$.

\section{Hexahydroisohumulone-modulated gene expression}

Using pathway-focused DNA arrays the transcriptional profiles were collected to characterize the major mechanistic pathway of HEX toxicity in canine liver, kidney and intestine. The comprehensive analysis of 370 genes, involved in 15 different functional pathways, demonstrated DNA damage/repair is the most extensively modulated pathway in HEX-treated hepatocytes (18 downregulated genes among 113 modified genes) and in CPTC (14 down-regulated genes among 80 genes) followed by fatty acid metabolism (15 downregulated)/apoptosis (15-downregulated genes) in hepatocytes and apoptosis (12 downregulated genes) in CPTC. In ELC, HEX mainly affected endoplasmic reticulum (ER) stress/unfolded protein response (4 upregulated genes among 18 genes) (Tables 2-6).

Under physiological condition, ROS/RNS are generated by the mitochondrial respiratory chain and enzyme-catalyzed reactions with NADPH oxidase, xanthine oxidase, arachidonic acid metabolism-related cyclooxygenases (COXs) and CYP450s; are counteracted by the various antioxidant enzymes, such as SOD, NCOA7, NQO1, GST superfamily, and glutathione peroxidases (GPXs) [43-45]. In this study, HEX at the cytotoxic concentrations $(0.11 \mathrm{mg} / \mathrm{mL}$ in hepatocytes and $0.05 \mathrm{mg} / \mathrm{mL}$ in CPTC) suppressed antioxidant enzyme systems including GPX3, GSTA3, NQO1 and SOD1 in canine hepatocytes and to a lesser extent in CPTC, whereas NQO1 was activated only in ELC (Tables 3 and 4). These findings support that HEX exerts cell type-specific response of an oxidative/nitrative stress in canine hepatocytes and to a less extent CPTC (Figure 1 and 3). The integrity of the cellular genome is often challenged by reactive by-product such as ROS/RNS from normal cellular metabolism as well as exogenous agents present in the air, food, water and other sources. The resulting oxidative DNA damage can be counteracted by various repair mechanisms for a specific lesion [46]. HEX greatly inhibited the expression of DNA double strand repair genes and to a lesser degree the genes in nucleotide excision repair, DNA mismatch repair and base excursion repair as well as repair enzymes for oxidative DNA/RNA damage such as NUDT1/NUDT15 (Table 3). This result substantiates the finding that oxidative stress suppresses the levels of DNA repair proteins $\mathrm{Ku} 80$, encoded by XRCC5 gene, and Ku70, encoded by
XRCC6 gene, in rat AR42J pancreas epithelial cell line [47].

HEX at cytotoxic concentrations modulated the expression of different target genes involved in cell death and survival with various magnitudes of transcriptional levels, in hepatocytes and to a less extent CPTC (Table 2). These results suggest that the increase in ROS/RNS levels (Figure 1 and 3) may be the primary cause of HEX-mediated cytotoxicity in canine hepatocytes, but the secondary cause in CPTC because its concentration corresponding to the increase in ROS/RNS levels in CPTC is greater than its cytotoxic level $\left(\mathrm{LC}_{50}, 0.03 \mathrm{mg} / \mathrm{mL}\right)$ [14]. Previous study reported that other hop components such as humulone and $\beta$-acids hop didn't induce cell survival-related molecules, BCL-2 and BCL-X but activated cell death-related CASP3 and CASP9 as well as cytochrome $\mathrm{c}$ release in a human leukemia HL-60 cell line [48].

HEX extensively inhibited the expression levels of fatty acid metabolism (mitochondrial $\beta$-oxidation)-related genes in canine hepatocytes and CPTC (Table 5). Fatty acid, incompletely oxidized in the mitochondria, results in an increase in esterification into triglycerides leading to its accumulation in the liver [49]. Further severe damage to mitochondrial $\beta$-oxidation limits ATP production leading to defects in ATP-dependent pathways such as ureagenesis and gluconeogenesis in the liver [49]. HEX comprehensively modulated endoplasmic reticulum (ER) stress/ unfolded protein response (UPR)-mediated genes in canine hepatocytes and CPTC. The proper folding of proteins in ER is crucial for cell survival and normal physiological functions. Thus, the improperly folded proteins can elicit ER stress and UPR leading to ROS accumulation [43]. HEX extensively induced COX-2 and CHOP in canine hepatocytes and CPTC (Tables 4 and 5). Previous studies show that COX-2 and CHOP are both associated with cell death and survival in pathophysiological processes and secretion of proinflammatory cytokines [5052, 57-59]. CHOP participates in ER stress-induced apoptosis through the interaction with other transcriptional factors such as activating transcription factor-4 (ATF4), activator protein 1 (AP$1)$ as well as ER oxidase $1 \alpha(\mathrm{ERO} 1 \alpha)$, resulting in the reduction of cell survival-related BCL-2 and MCL1 and an induction of cell death-related $\mathrm{BH} 3$ only at protein level [50]. In this study, HEX induced ER-stress markers such as ATF4 and ERO1 $\alpha$ in the kidney associated with a decrease in BCL2L1 and MCL1 (Tables 2 and 7). COX-2 and CHOP mediate prostaglandin E2 (PGE2)-induced interleukin-8 (IL-8) production in cystic fibrosis airway epithelial cells, IB3-1 and CFTE [52]. COX-2 sustains cell survival regulation in human colon carcinoma cells HT29 by augmenting COX-2 and PGE2 and in lung adenocarcinoma (CL1.0 cells) by an increase in MCL1 through activating phosphatidylinositol 3-kinase (PI3K)/Akt signaling pathway [51, 57]. COX-2 and Akt, known as protein kinase B (PKB) reclaimed human neuroblastoma-motor neuron cell line, HMN1 and rat cholangiocarcinoma cells from apoptosis by deactivating CASP9 and CASP3 [58, 59]. Additionally, COX-2, an inducible gene by various stimuli, catalyzed the synthesis of prostaglandins (PGs) from arachidonic acid and showed an increase with mammary tumors in dogs and humans, and in chronic kidney disease in dogs and cats [51-56]. In this study COX-2/CHOP-mediated pro-apoptotic (cell death) and anti-apoptotic (cell survival) genes; as well as a cytokine, IL-8 mRNA predominantly changed in HEX-treated hepatocytes and/or CPTC (Tables 2 and 4). In mitochondrial metabolism, HEX inhibited the expression of 
citric acid cycle-related enzymes, such as ACYL, ACO2, FH, MDH1 and SDHD as well as IDH isoforms in the liver and/or the kidney over time (Table 6). This result correlates to a previous study that showed mitochondrial COX-2 inhibited IDH catalytic activity toward isocitrate by altering ligand binding at the catalytic site [60]. Antimycin A-induced mitochondrial dysfunction caused an increase in COX-2 level in human chondrocytes [61]. Thus, it is likely that COX-2 and CHOP play a significant role in HEXmediated cellular response in hepatocytes and CPTC. However, the ELC exposed to HEX showed an increase in proapoptotic genes such as ABL1 and TP53. When these results were compared to the cytotoxicity of HEX after $24 \mathrm{hr}$ derived from in vitro canine cell systems, the extent of gene alteration was inversely correlated with the degree of HEX toxicity in hepatocytes (113 genes at $0.12 \mathrm{mg} / \mathrm{mL}$ of $\mathrm{LC}_{50}$ value of HEX), in CPTC ( 80 genes at $0.037 \mathrm{mg} / \mathrm{mL})$ and in ELC (18 genes at $0.023 \mathrm{mg} / \mathrm{mL})$ [14]. These results suggest that the hepatocytes exert more extensive metabolic function and biochemical defense against HEX compared to the excretory proximal tubule epithelial cells and the absorptive enterocytes. The enterocytes predominantly account for the enzymatic digestion and the maximal absorptive capacity with a limited life span and have a defined biochemical function and metabolic capacity compared to the liver, which may make them easily susceptible to HEX-induced adverse effects [62].

In Phase I and Phase II drug metabolism, HEX caused an organ-specific inhibition of CYP3A12, CES2, ESD, PON1 and GSTA3 in the liver and CYP1B1, CYP19A1, FMO4 and FMO5 in the kidney, whereas it showed induced GSTM1 in the intestine (Table 3). This result correlates to a previous study that the hop component, xanthohumulone attenuated the catalytic activity of human CYP1B1 toward 7-tethoxyresorufin O-deethylase (EROD) indicating a potential metabolic interaction between CYP1B1 substrates and isohumulone leading to serious adverse effects [38].

In summary, this research provides a mechanistic insight into how HEX can lead to species-specific toxicity on dogs and their organ-specific toxicity using in vitro-derived data. This study demonstrates the potential molecular crosstalk of COX-2 and CHOP between various pathways and characterizes a separate but complementary action of COX-2/CHOP in HEX-mediated adverse effect on the cellular functions (Figure 4). The study of dose-dependent transitions in toxicity mechanisms with less sensitive concentrations of HEX in these cell systems, and coupled with adsorption, distribution, metabolism and excretion (ADME) properties of HEX would provide more accurate and reliable data on the safe levels of HEX consumption for dogs. Previous in vivo studies showed nonsteroidal anti-inflammatory drugs (NSAIDs) suppressing COX-2 caused species difference in nephrotoxic responses between the dog, rat, mice and monkey [63, 64]. So, it is reasonable to assume that the safety level of COX-2mediated HEX response from a species does not guarantee safety in all species. Thus, the mechanism-derived information on HEX toxicity can be further utilized to assess the safety at the current levels of HEX occurring in foods among the different animals and humans.

\section{Acknowledgement}

This research was supported by Mars Inc. Global Quality and
Food Safety, McLean, VA. Parts of this research were presented at the $54^{\text {th }}$ annual meeting of the National Society of Toxicology in San Diego, CA.

\section{References}

[1]. Koetter U, Biendl M (2010) Hops (Humulus Iupulus): A review of its historic and medicinal uses. Herbal Gram 87: 44-57.

[2]. Chappel CI, Smith SY, Chagnon M (1998) Subchronic toxicity study of tetrahydroisohumulone and hexahydroisohumulone in the beagle dog. Food Chem Toxicol 36(11): 915-922.

[3]. Nord LI, Sørensen SB, Duus JØ (2003) Characterization of reduced isoalpha-acids derived from hops (Humulus lupulus) by NMR. Magn Reson Chem 41(9): 660-670.

[4]. Todd PH, Held RW, Guzinski JG (1996) The development and use of modified hop extracts in the art of brewing. Tech Quarterly Mater Brew Assoc Am 33(2): 91-95.

[5]. Nozawa H, Nakao W, Zhao F, Kondo K (2005) Dietary supplement of isohumulones inhibits the formation of aberrant crypt foci with a concomitant decrease in prostaglandin E2 level in rat colon. Mol Nutr Food Res 49(8): $772-778$.

[6]. Everard A, Geurts L, Roye MV, Delzenne NM, Cani PD (2012) Tetrahydro iso-Alpha Acids from Hops Improve Glucose Homeostasis and Reduce Body Weight Gain and Metabolic Endotoxemia in High-Fat Diet-Fed Mice. PLoS ONE 7(3): e33858.

[7]. Konda VR, Desai A, Darland G, Bland JS, Tripp ML (2009) Rho iso-alpha acids from hops inhibt the GSK-3/NF-kB pathway and reduce inflammatory markers associated with bone and cartilage degradation. J Inflamm 6: 26.

[8]. Miura Y, Hosono M, Oyamada C, Odai H, Oikawa S, et al. (2005) Dietary isohumulones, the bitter components of beer, raise plasma HDL-cholesterol levels and reduce liver cholesterol and triacylglycerol contents similar to PPAR alpha activations in C57BL/6 mice. Br J Nutr 93(4): 559-567.

[9]. Yajima H, Ikeshima E, Shiraki M, Kanaya T, Fujiwara D, et al. (2004) Isohumulones, bitter acids derived from hops, activate both peroxisome proliferator-activated receptor alpha and gamma and reduce insulin resistance. J Biol Chem 279(32): 33456-33462.

[10]. Yajima H, Noguchi T, Ikeshima E, Shiraki M, Kanaya T, et al. (2005) Prevention of diet-induced obesity by dietary isomerized hop extract containing isohumulones, in rodents. Int J Obes 29(8): 991-997.

[11]. Lee JC, Kundu JK, Hwang DM, Na HK, Surh YJ (2007) Humulone inhibits phorbol ester-induced COX-2 expression in mouse skin by blocking activation of NF-kappaB and AP-1: IkappaB kinase and c-Jun-N-terminal kinase as respective potential upstream targets. Carcinogenesis, 28(7): 1491-1498.

[12]. Hall AJ, Babish JG, Darland GK, Carroll BJ, Konda VR, et al. (2008) Safety, efficacy and anti-inflammatory activity of rho iso-alpha-acids from hops. Phytochemistry 69(7): 1534-1547.

[13]. Hougee S, Faber J, Sanders A, Berg WB, Garssen J, et al. (2006) Selective inhibition of COX-2 by a standardized $\mathrm{CO} 2$ extract of Humulus lupulus in vitro and its activity in a mouse model of zymosan-induced arthritis. Planta Med 72(3): 228-233.

[14]. Monteiro-Riviere NA, Ortega MT, Choi K, Koci J, Lin Z, et al. (2015) Comparative In Vitro Cytotoxicity of 20 Potential Food Ingredients in Canine Liver, Kidney and Bone Marrow-Derived Mesenchymal Stem Cells, and Enterocyte-like Cells. Appl In Vitro Toxicol 1(4): 276-288.

[15]. Duncan KL, Hare WR, Buck WB (1997) Malignant hyperthermia-like reaction secondary to ingestion of hops in five dogs. J Am Vet Med Assoc 210(1): 51-54.

[16]. Food and Drug Administration (FDA), 2002, Available: http://www.fda. gov/ohrms/dockets/98fr/00c-0929-nfr0001-vol1.pdf

[17]. Eisenbrand G, Pool-Zobel BP, Baker V, Ball M, Blaauboer BJ, et al. (2002) Methods of in vitro toxicology. Food Chem Toxicol 40(2-3): 193-236.

[18]. Lilienblum W, Dekant W, Foth H, Gebel T, Hengstler JG, et al. (2008) Alternative methods to safety studies in experimental animals: role in the risk assessment of chemicals under the new European Chemicals Legislation (REACH). Arch Toxicol 82(4): 211-236.

[19]. National Research Council (NRC), National Academy Press, Washington DC (2008) Available: http://dels.nas.edu/resources/static-assets/materialsbased-on-reports/reports-in-brief/satety_of_dietary_supplements_final.pdf

[20]. Walton K, Walker R, van de Sandt JJ, Castell JV, Knapp AG, et al. (1999) The application of in vitro data in the derivation of the acceptable daily intake of food additives. Food Chem Toxicol 37(12): 1175-1197.

[21]. Buick JK, Moffat I, Williams A, Swartz CD, Recio L, et al. (2015) Integration of metabolic activation with a predictive toxicogenomics signature to classify genotoxic versus nongenotoxic chemicals in human TK6 cells. Environ Mol Mutagen 56(6): 520-534. 
[22]. Choi YG, Seok YH, Yeo S, Jeong MY, Lim S (2011) Protective changes of inflammation-related gene expression by the leaves of Eriobotrya japonica in the LPS-stimulated human gingival fibroblast: microarray analysis. J Ethnopharmacol 135(3): 636-645.

[23]. Hsu S, Yu FX, Huang Q, Lewis J, Singh B, et al. (2003) A mechanism-based in vitro anticancer drug screening approach for phenolic phytochemicals. Assay Drug Dev Technol 1(5): 611-618.

[24]. Kleinstreuer NC, Yang J, Berg EL, Knudsen TB, Richard AM, et al. (2014) Phenotypic screening of the ToxCast chemical library to classify toxic and therapeutic mechanisms. Nat Biotechnol 32(6): 583-591.

[25]. Zhang LW, Koci J, Jeffery B, Riviere JE, Monteiro-Riviere NA (2015) Safety assessment of potential food ingredients in canine primary hepatocytes. Food Chem Toxicol 78: 105-115.

[26]. Koci J, Jeffery B, Riviere JE, Monteiro-Riviere NA (2015) In vitro safety assessment of food ingredients in canine renal proximal tubule cells. Toxicol In Vitro 29(2): 289-298.

[27]. Ortega MT, Jeffery B, Riviere JE, Monteiro-Riviere NA (2015) Toxicological effects of pet food ingredients on canine bone marrow derived mesenchymal stem cells and enterocyte-like cells. J Appl Toxicol 36(2): 189-198.

[28]. Dalleau S, Baradat M, Guéraud F, Huc L (2013) Cell death and diseases related to oxidative stress: 4-hydroxynonenal (HNE) in the balance. Cell Death Differ 20: 1615-1630.

[29]. Shukla V, Mishra SK, Pant HC (2011) Oxidative stress in neurodegeration. Adv Pharmacol Sci 1-13.

[30]. Shuhendler AJ, Pu K, Cui L, Uetrecht JP, Rao J (2014) Real-time imaging of oxidative and nitrosative stress in the liver of live animals for drug-toxicity testing. Nat Biotechnol 32: 373-380.

[31]. Rietjens IM, Boersma MG, Haan LD, Spenkelink B, Awad HM, et al. (2002) The pro-oxidant chemistry of the natural antioxidants vitamin C, vitamin E, carotenoids and flavonoids. Environ Toxicol Pharmacol 11(3-4): 321-333.

[32]. Namikoshi T, Tomita N, Fujimoto S, Haruna Y, Ohzeki M, et al. (2007) Isohumulones derived from hops ameliorate renal injury via an anti-oxidative effect in Dahl salt-sensitive rats. Hypertens Res 30(2): 175-184.

[33]. Bohr G, Klimo K, Zappa J, Becker H, Gerhäuser C (2008) Cancer chemopreventive potential of humulones and isohumulones (hops $\alpha$-and iso- $\alpha$ acids): Induction of $\mathrm{NAD}(\mathrm{P}) \mathrm{H}$ : quinone reductase as a novel mechanism. Nat Prod Commun 3: 1-6.

[34]. Yamaguchi N, Satoh-Yamaguchi K, Ono M (2009) In vitro evaluation of antibacterial, anticollagenase, and antioxidant activities of hop components (Humulus lupulus) addressing acne vulgaris. Phytomedicine 16(4): 369376.

[35]. Choi K, Ortega MT, Jeffery B, Riviere JE, Monteiro-Riviere NA (2015) Oxidative stress response in canine in vitro liver, kidney and intestinal models with seven potential dietary ingredients. Toxicol Lett 241: 49-59.

[36]. Hinnebusch BF, Siddique A, Henderson JW, Malo MS, Zhang W, et al. (2004) Enterocyte differentiation marker intestinal alkaline phosphatase is a target gene of the gut-enriched Kruppel-like factor. Am J Physiol Gastrointest Liver Physiol 286(1): G23-G30.

[37]. Gibbs JP, Liacouras CA, Baldassano RN, Slattery JT (1999) Up-regulation of glutathione S-transferase activity in enterocytes of young children. Drug Metab Dispos 27(12): 1466-1469.

[38]. Henderson MC, Miranda CL, Stevens JF, Deinzer ML, Buhler DR (2000) In vitro inhibition of human P450 enzymes by prenylated Flavonoids from hops, Humulus lupulus. Xenobiotica 30(3): 235-251.

[39]. Cattoor K, Remon JP, Boussery K, Van Bocxlaer J, Bracke M, et al. (2011) Bioavailability of hop-derived iso- $\alpha$-acids and reduced derivatives. Food Funct 2(7): 412-422

[40]. Schroeder A, Mueller O, Stocker S, Salowsky R, Leiber M, et al. (2006) The RIN: an RNA integrity number for assigning integrity values to RNA measurements. BMC Mol Biol 7: 3.

[41]. Paolini M, Antelli A, Pozzetti L, Spetlova D, Perocco P, et al. (2001) Induction of cytochrome P450 enzymes and over-generation of oxygen radicals in beta-carotene supplemented rats. Carcinogenesis 22(9): 1483-1495.

[42]. Zhang R, Niu Y, Li Y, Zhao C, Song B, et al. (2010) Acute toxicity study of the interaction between titanium dioxide nanoparticles and lead acetate in mice. Environ Toxicol Pharmacol 30(1): 52-60.

[43]. Gorrini C, Harris IS, Mak TW (2013) Modulation of oxidative stress as an anticancer strategy. Nat Rev Drug Discov 12(12): 931-947.

[44]. Yu L, Croze E, Yamaguchi KD, Tran T, Reder AT, et al. (2015) Induction of a unique isoform of the NCOA7 oxidation resistance gene by interferon $\beta$-1b. J Interferon Cytokine Res 35(3): 186-199.

[45]. Evans MD, Saparbaev M, Cooke MS (2010) DNA repair and the origins of urinary oxidized 2'-deoxyribonucleosides. Mutagenesis 25(5): 433-442.

[46]. Lu AL, Li X, Gu Y, Wright PM, Chang DY (2001) Repair of oxidative DNA damage: mechanisms and functions. Cell Biochem Biophys 35(2): 141-170.

[47]. Song J, Lim J, Kim H, Morio T, Kim K (2003) Oxidative stress induces nuclear loss of DNA repair proteins $\mathrm{Ku} 70$ and $\mathrm{Ku} 80$ and apoptosis in pancreatic acinar AR42J cells. J Biol Chem 278(38): 36676-36687.

[48]. Chen WJ, Lin JK (2004) Mechanisms of cancer chemoprevention by hop bitter acids (beer aroma) through induction of apoptosis mediated by Fas and caspase cascades. J Agric Food Chem 52(1): 55-64.

[49]. Fromenty B, Pessayre D (1995) Inhibition of mitochondrial beta-oxidation as a mechanism of hepatotoxicity. Pharmacol Ther 67(1): 101-154.

[50]. Tabas I, Ron D (2011) Integrating the mechanisms of apoptosis induced by endoplasmic reticulum stress. Nat Cell Biol 13(3): 184-190.

[51]. Roberts HR, Smartt HJ, Greenhough A, Moore AE, Williams AC, et al. (2011) Colon tumour cells increase PGE2 by regulating COX-2 and 15PGDH to promote survival during the microenvironmental stress of glucose deprivation. Carcinogenesis 32: 1741-1747.

[52]. Vij N, Amoako MO, Mazur S, Zeitlin PL (2008) CHOP transcription factor mediates IL-8 signaling in cystic fibrosis bronchial epithelial cells. Am J Respir Cell Mol Biol 38(2): 176-184.

[53]. Queiroga FL, Pires I, Lobo L, Lopes CS (2010) The role of Cox-2 expression in the prognosis of dogs with malignant mammary tumours. Res Vet Sci 88(3): 441-445.

[54]. Nowak M, Madej JA, Dziegiel P (2007) Intensity of COX2 expression in cells of soft tissue fibrosarcomas in dogs as related to grade of tumor malignancy. Bull Vet Inst Pulawy 51: 275-279.

[55]. Dannenberg AJ, Altorki NK, Boyle JO, Dang C, Howe LR, et al. (2001) Cyclo-oxygenase 2: a pharmacological target for the prevention of cancer Lancet Oncol 2(9): 544-551.

[56]. Yabuki A, Mitani S, Sawa M, Mizukami K, Fujiki M, et al. (2012) A comparative study of chronic kidney disease in dogs and cats: induction of cyclooxygenases. Res Vet Sci 93(2): 892-897.

[57]. Lin MT, Lee RC, Yang PC, Ho FM, Kuo ML (2001) Cyclooxygenase-2 inducing Mcl-1-dependent survival mechanism in human lung adenocarcinoma CL1.0 cells. Involvement of phosphatidylinositol 3-kinase/Akt pathway. J Biol Chem 276(52): 48997-49002.

[58]. Zhou H, Li XM, Meinkoth J, Pittman RN (2000) Akt regulates cell survival and apoptosis at a postmitochondrial level. J Cell Biol 151(3): 483-494.

[59]. Zhang Z, Lai GH, Sirica AE (2004) Celecoxib induced apoptosis in rat cholangiocarcinoma cells mediated by Akt inactivation and Bax translocation. Hepatology 39(4): 1028-1037.

[60]. Anderson SL, Lin AP, McAlister-Henn L (2005) Analysis of interactions with mitochondrial mRNA using mutant forms of yeast $\mathrm{NAD}(+)$-specific isocitrate dehydrogenase. Biochemistry 44(50): 16776-16784.

[61]. Cillero-Pastor B, Caramés B, Lires-Deán M, Vaamonde-García C, Blanco FJ, et al. (2008) Mitochondrial dysfunction activates cyclooxygenase 2 expression in cultured normal human chondrocytes. Arthritis Rheum 58(8): 2409-2419.

[62]. Kaminsky LS, Zhang QY (2003) The small intestine as a xenobiotic-metabolizing organ. Drug Metab Dispos 31(12): 1520-1525.

[63]. Sellers RS, Senese PB, Khan KN (2004) Interspecies differences in the nephrotoxic response to cyclooxygenase inhibition. Drug Chem Toxicol 27(2): $111-122$.

[64]. Kim G (2008) Renal Effects of Prostaglandins and Cyclooxygenase-2 Inhibitors. Electrolyte Blood Press 6(1): 35-41. 